\title{
Biotic and Abiotic Factors Causing Rind Blemishes in Citrus and Management Strategies to Improve the Cosmetic Quality of Fruits
}

\author{
Aman Ullah Malik ${ }^{1 *}$, Mahmood UI Hasan', Samina Khalid ${ }^{2}$, Muhammad Sohail Mazhar ${ }^{3}$, Muhammad Shafique \\ Khalid $^{2}$, Muhammad Nawaz Khan ${ }^{4}$, Basharat Ali Saleem ${ }^{5}$, Ahmad Sattar Khan ${ }^{1}$ and Raheel Anwar ${ }^{1}$ \\ ${ }^{1}$ Postharvest Research and Training Centre, Institute of Horticultural Sciences, University of Agriculture, Faisalabad, \\ Pakistan \\ ${ }^{2}$ Department of Environmental Sciences, COMSATS Institute of Information Technology, Vehari, Pakistan \\ ${ }^{3}$ Department of Agriculture and Fisheries, Queensland, Portsmith, Australia \\ ${ }^{4}$ Citrus Research Institute, Sargodha, Pakistan \\ ${ }^{5}$ Punjab Agriculture (Extension) Department, Fruit and Vegetable Development Project, Sargodha, Pakistan \\ *For correspondence: malikaman1@gmail.com; malikaman1@uaf.edu.pk \\ Received 10 August 2020; Accepted 15 October 2020; Published 10 January 2021
}

\begin{abstract}
Citrus is the major tree fruit crop grown and traded worldwide. Citrus industry around the globe has been facing deterioration in fruit cosmetic quality and increased farmgate rejections, mainly due to high incidence of rind blemishes. Rind blemishes are caused by various biotic (diseases and insects) and abiotic (environmental, physical and physiological) factors at various stages of fruit development, however initial 8-12 weeks of fruit setting are the most critical. While the causes and intensity of blemishes varies with agroecological conditions and citrus species, and fruits position in canopy, the blemishes due to melanose, scab, canker, thrips, mites, scales, and wind are generally the most common. Being a complex issue involving multiple factors in the field (environment, pathogens, tree, fruit, cultural practices), its control has always been very challenging. R\&D progress overtime showed a great deal of work done on the subject, however for commercial success, an integrated approach is essential to reduce rind blemishes and improve fruits cosmetic quality. The key interventions include maintaining tree vigor and hygiene with judicial pruning, selective and timely application of pesticides at critical stages, particularly during initial 12 weeks of fruit development. Keeping in view the increasing concerns regarding food safety, the application of horticultural mineral oils (HMOs) and effective biological tools need to be integrated. To some degree, harvest and postharvest supply chain operations may also contribute towards some fruit blemishes (oleocellosis, rind/stem end breakdown, chilling injury, etc.) and are to be managed appropriately. While various advance technologies i.e., near-infrared (NIR), ultraviolet (UV), ultraviolet fluorescence (UVF), laser backscattering imaging (LBI) and hyperspectral imaging (HI) have been tested /developed for blemish-based fruit sorting, their high cost is prohibitive in adaptation particularly in developing countries. Future research needs to focus on assessing the impact of climate change on dynamics of biotic factors, blemish free fruit production under small tree-framework system, development of new chemistry low residue pesticides, reducing cost of high-tech sorting machines and consumer education to have acceptance of blemished fruit (still with good internal quality) to some degree. (C) 2021 Friends Science Publishers
\end{abstract}

Keywords: Citrus fruit blemishes; Farmgate rejection; Multiple factors; Supply chain

\section{Introduction}

Citrus is the second most grown fruit crop, ranked next to grapes, in the world having significant social as well as economic impact on society (Nasir et al. 2016). It is cultivated in sub-tropical and tropical regions and comprises of several valuable commercial fruit species including mandarins, oranges, limes, lemons and grapefruit. Worldwide, annual production of citrus is 194.35 million tonnes, with export quantity of > 15.91 million tonnes. China, Brazil, India, Mexico, U.S.A. and are the leading citrus producing countries, with Pakistan ranking at $16^{\text {th }}$ position (FAOSTAT 2018).

External (cosmetic) appearance of fruit is an important criterion affecting the choice of the produce by the consumers in the market (Danedekar 2004). Consumers demand shiny, attractive, clean, and blemish free fruits (Chaparro 2004). The cosmetic appearance of the fruit is visual parameter for judgment of quality throughout the supply chain (production, marketing, retail and consumption) (Khalid 2013). Generally, in fruit quality, peel color is a widely studied parameter (Dobrzanski and

To cite this paper: Malik AU, MU Hasan, S Khalid, MS Mazhar, MS Khalid, MN Khan, BA Saleem, AS Khan, R Anwar (2021). Biotic and abiotic factors causing rind blemishes in citrus and management strategies to improve the cosmetic quality of fruits. Intl J Agric Biol 25:298-318 
Rybczynski 2002). Primary color is stated as the uniformly and homogeneously distributed color on skin of fruit. Uniform colored skin is an indicator of good quality. Citrus usually has uniform distribution of color around the fruit surface and this is believed as a quality mark. Citrus fruit is hesperidium berry composed of three main sections, namely (from inside) endocarp or pulp, mesocarp or albedo, and the exocarp or flavedo, both mesocarp and exocarp together make the pericarp (the peel or rind) (Ladaniya 2008). Flavedo is covered with a thin layer of protective cuticle. Flavedo is composed of the epidermal cells (isodiametric and polygonal) and lacks the intercellular spaces (Agustí et al. 2001). Oil glands embedded in the epidermis surround the hypodermal parenchymatous cells. These cells are round to oval, thin walled, with distant vacuoles and have small intercellular spaces. These cells increase progressively in size deeper in the rind (Agustí et al. 2001; Ladaniya 2008) (Fig. 1) and any damage to oil glands lead to discoloration or blemish. Conclusively, blemishes are morphologically distorted, shrunken, deformed and collapsed hypodermal tissues with destructed oil glands on rind (Safran 1975; Petracek et al. 1998) and look different from the typical fruit color.

Multiple factors are involved in causing rind blemishes, which can be generally grouped as biotic and abiotic in nature. Abiotic factors include environmental (wind, sun burn), physical, nutritional imbalance, while biotic factors include myriad of various pests, diseases (fungal or bacterial) and micro-organisms, which downgrade the external quality of fruit (Albrigo 1978; Ahmed 2005) and are considered as the major cause. A survey conducted in main citrus (Kinnow mandarin) growing districts in Punjab, Pakistan, revealed that farmgate rejection of Kinnow fruit ranged from $20-50 \%$, due to high blemishes leading to poor cosmetic quality (Malik and Khan 2014). Such a high farmgate rejection and price difference in various quality grades significantly affects the grower's net returns and makes crop production unsustainable. Further the price difference between A-grade (minor or no blemish) and B grade (moderately blemished) Kinnow mandarin at farmgate is almost double. Although, blemished and non-blemished citrus fruits of similar size displayed no significant difference for internal fruit quality in terms of biochemical (soluble solid contents, acidity) and organoleptic (taste, flavor and texture) evaluation (Malik and Khan 2014). While there has been good work done in various citrus producing countries, on fruit blemishes (Albrigo 1978; Agustí et al. 1997; Alférez et al. 2003), an updated review is currently lacking. It is very important to comprehensively review the published literature to have a clear understanding about types and intensity of blemishes, causal agents, R\&D progress, and possible strategies to reduce blemishes and improve cosmetic quality of fruit. Previously published reviews and significant research work on citrus fruit blemishes is almost three decades old (Albrigo 1972; Safran 1975; Albrigo 1976, 1978), while the later studies on fruit blemishes were more focused on postharvest aspects (Alférez et al. 2003, 2008; Ahmed 2005; Alférez et al. 2010; Futch 2011; Zacarias et al. 2020). Overtime, the progress has been made starting from farm factors like blemish profile with respect to tree position, tree hygiene, advance chemistry fungicides, use of biological control agents, advancements in precision agricultural technologies to optimize pest and disease identification and management (Ampatzidis 2019; Partel et al. 2019), to the use of machine vision for fruit sorting based on skin blemishes (Zhang et al. 2018). Hence, this article presents an updated review on citrus fruit blemishes, causal factors, control strategies along with identifying gaps in knowledge and technology and suggest future research needs.

\section{Blemish development, intensity and distribution}

Rind blemishes are developed on fruit surface at various developmental stages and involve several factors as shown in a Tree-Fruit Environmental Profile of Kinnow mandarin (Fig. 2). The study showed that maximum fruit blemishes (>60\%) on the surface of Kinnow mandarin were developed within eight weeks of fruit setting (April-May) (Khalid 2013). An earlier study mentioned that rind blemishes start developing at the onset of fruit setting for 12 weeks and these cannot be minimized in later stages of fruit development (Freeman 1976). Hence, the period of eight to twelve weeks after fruit setting is critical for reducing rind blemishes.

Percentage of blemishes largely depends upon the production technology being used in orchards (Zekri et al. 2003). However, severity of causal factors like diseases and pest pressure also depends upon geographical conditions; being more in tropical humid areas than in arid, semi-arid and cool regions. Types and intensity of fruit blemishes may also vary with respect to tree canopy position: more windborne blemishes on top, higher fungal linked and red scales blemishes at lower portion of canopy, and more greening incidence in center of canopy (Mazhar et al. 2016), which clearly reflects need for understanding the types and location of blemishes on tree, and devise specific management strategies (Fig. 3).

\section{Blemish rating scale}

Most of the blemish related research studies conducted on Kinnow mandarin used visual rating scale based on CODEX quality standards (Anonymous 1999) with certain modifications by categorizing into six groups: $1:<1 \mathrm{~cm}^{2}, 2$ : 1-5\%, 3: 6-10\%, 4: 11-25\%, 5: $26-50 \%$ and 6: $>50 \%$, (Ahmed 2005; Khalid et al. 2012b; Hasan 2018; Jahangir 2018; Waqas 2019). While at commercial level, after harvest, Kinnow fruit is categorized visually, in A (minor or no blemish), B (moderately blemish-local market) and Cgrade (reject/juice purpose only) at farmgate. 


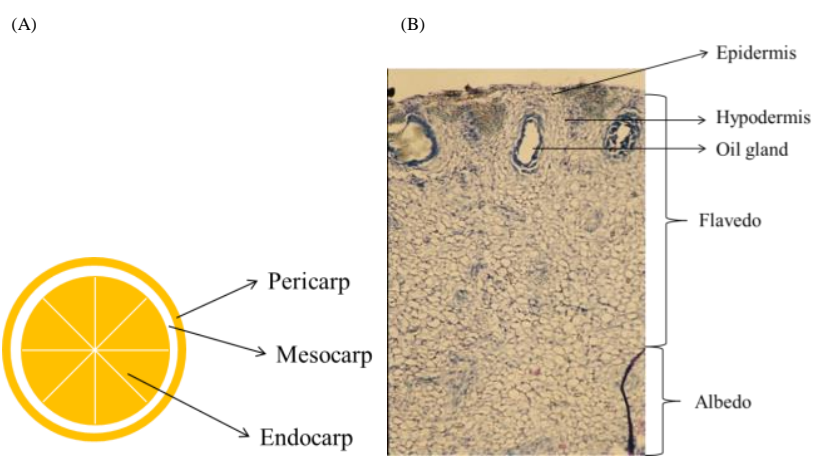

Fig. 1: Citrus fruit parts (a) and transection of citrus rind (b).

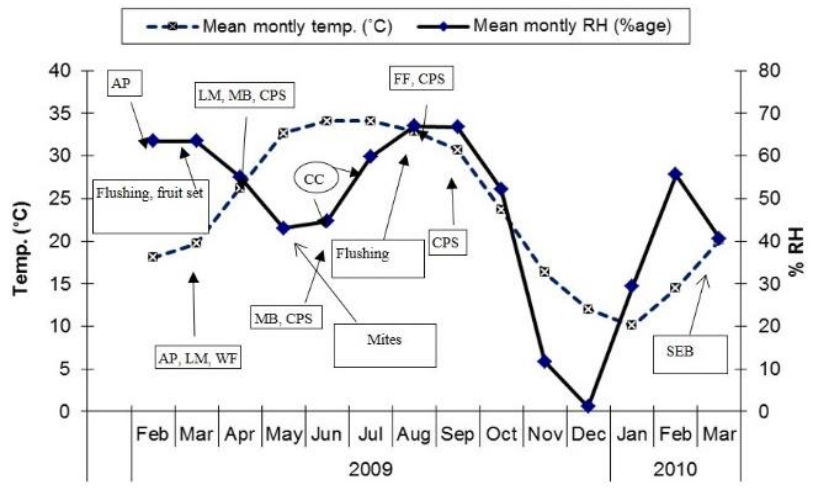

Fig. 2: A Tree-Fruit-Environment (TFE) Profile of Kinnow mandarin (Sargodha, Pakistan) showing the timeline of phenological stages of tree in relation to environment, fruit growth and developmental stages, disease and pest attack $(\mathrm{AP}=$ Aphid, $\mathrm{LM}=$ Leaf Miner, $\mathrm{MB}=$ Mealy Bug, $\mathrm{CPS}=$ Citrus Psylla, $\mathrm{FF}=$ Fruit Fly, WF $=$ White Fly, Mt= Mites, $\mathrm{CC}=$ Citrus canker, $\mathrm{SEB}=$ Stem end breakdown)

Source: Khalid (2013)

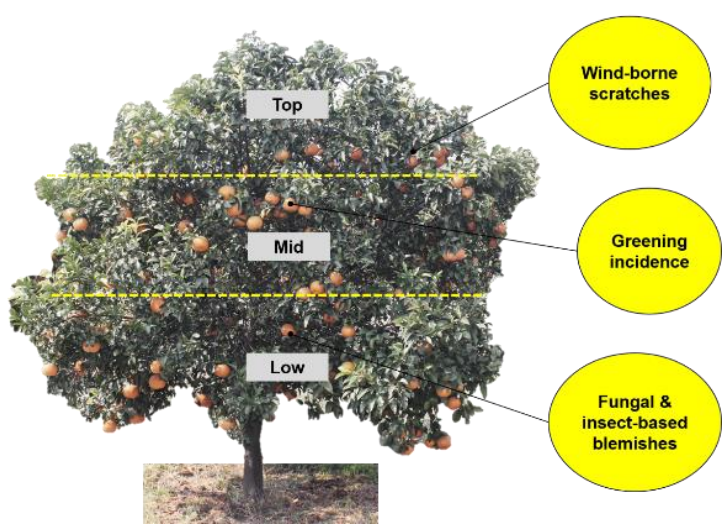

Fig. 3: A tree -model showing the distribution of different type of blemishes with respect to canopy position where predominantly wind born scratches observed on top, greening incidence in the mid-section and fungal based blemishes along-with red scales, more apparent in lower canopy side reflects the need for good understanding about the type and location of fruit blemishes with relevant management strategies

Source: Mazhar et al. (2016)
For academic reasons, based on nature of blemishes, two major categories are made i.e., abiotic (physical, wind) and biotic (thrips, mites, scales and melanose, scab) group. Apart from these classifications, in the world, various quality monitoring systems have been adopted for the detection of defects, in fruits and vegetables (tomatoes, potatoes, oranges, mandarin and plums) such as dry rot, cracks, skin rub etc. (Budagovskaya 1997). For a better understanding and from management perspectives, biotic and abiotic factors-based grouping is more convenient and will be followed in this paper.

\section{Causes of blemishes}

Albrigo (1978) reported about 80 different causes responsible for off-grade production of citrus fruit. Beside the major contribution of above-mentioned factors during crop production cycle, processing techniques (Wild 1998; Cronje 2007), packaging material (Ben-Yehoshua et al. 2001), and storage conditions (Porat et al. 2004) may also affect development of blemishes on fruit peel during various stages of supply chain. A detailed account of various causal factors/blemish types is detailed below.

\section{Blemishes caused by biotic factors}

Pathogens: Citrus groves remain susceptible to many pathogens during most part of their annual growth and fruit development. Pathogens can damage the plant as well as deteriorate the external and /or internal fruit quality. Most of the diseases which cause significant external damage to citrus belong to fungi group. Particularly, the melanose and scab have recently become the major cause of deteriorating cosmetic quality of Kinnow mandarin in Pakistan. Pathological analysis of blemished Kinnow fruit samples showed the prevalence of Elsino fawcettii, Alternaria alternata, Colletotrichum gloeosporioides and Fusarium oxysporum as major pathogens (Malik and Khan 2014) (Fig. 4). These are followed by bacterial diseases, such as citrus canker and greening (Ahmed 2005) (Table 1).

\section{Citrus scab}

Citrus scab is the most known pathogen in citrus growing regions of the world. This is caused by pathogenic fungus Elsinoe fawcettii Bitancourt and Jenkins, which is widely distributed in the rain fed conditions (Gopal et al. 2014a). Warm, humid weather and dense, shaded, and damp soil conditions of citrus groves are most liking environment for the development of this disease. As it is fungal disease, spores in the form of 'conidia' are considered as initial inoculum for the spread of disease at the field level. There are two forms of conidia produced by concerning disease such as hyaline conidia and spindle conidia helpful in the development of lesions. Fungal spores start spreading just after onset of new flushes and fruit setting. All citrus 
Table 1: Important diseases downgrading cosmetic fruit quality of citrus and their possible management

\begin{tabular}{|c|c|c|c|c|}
\hline Disease & Causal agent & Symptoms/mechanism of damage & Control & References \\
\hline Citrus scab & $\begin{array}{l}\text { Elsinoe } \\
\text { fawcettii } \\
\text { Bitancourt }\end{array}$ & $\begin{array}{l}\text { Fungal disease; affect all plant parts; Small translucent } \\
\text { lesions appeared initially expands into lesions cause } \\
\text { cosmetic quality }\end{array}$ & $\begin{array}{l}\text { Two to three sprays of fungicides at } \\
\text { different stages; overhead sprinkler } \\
\text { irrigation; allamanda leaf, lemon grass } \\
\text { and parthenium extracts }\end{array}$ & $\begin{array}{l}\text { Chung (2011); Siddiquee } \\
\text { et al. (2011); Gopal et al. } \\
\text { (2014a); Rehman et al. } \\
\text { (2016) }\end{array}$ \\
\hline $\begin{array}{l}\text { Citrus } \\
\text { melanose }\end{array}$ & Diaporthe citri & $\begin{array}{l}\text { Spots similar to scab with smart netting with different } \\
\text { patterns such as tear drop, star and mud cake }\end{array}$ & $\begin{array}{l}\text { Spray of copper-based fungicides; } \\
\text { Nativo application at } 0.6 \mathrm{~g} / \mathrm{L}\end{array}$ & $\begin{array}{lr}\text { Gopal et al. } & (2014 \mathrm{~b}) ; \\
\text { Dewdney } & (2016) ; \\
\text { Anonymous } & (2017) ; \\
\text { et al. } \text { (2018) }\end{array}$ \\
\hline anker & $\begin{array}{l}\text { Xanthomonas } \\
\text { campestris pv } \\
\text { citri }\end{array}$ & $\begin{array}{l}\text { Watery spots on surface of thorns, leaves, twigs and } \\
\text { fruits prolongs into corky and brownish and necrotic } \\
\text { lesions }\end{array}$ & $\begin{array}{l}\text { Copper based fungicides; streptomycin } \\
\text { / phytomycin; extract spray of } \\
\text { Tamarindus indica (fruit pulp) }\end{array}$ & $\begin{array}{l}\text { Leksomboon } \text { et al. }(2001) \text {; } \\
\text { Javed et al. (2007); } \\
\text { Behlau } \text { et al. }(2017) \text {; }\end{array}$ \\
\hline $\begin{array}{l}\text { Citrus } \\
\text { greening }\end{array}$ & $\begin{array}{l}\text { Candidatus } \\
\text { liberibacter } \\
\text { asiaticus }\end{array}$ & $\begin{array}{l}\text { All plant parts including leaves, twigs, roots and fruits; } \\
\text { symptoms like Zn deficiency with interveinal chlorosis; } \\
\text { trees showed inferior quality fruits with poor colour }\end{array}$ & $\begin{array}{l}\text { Control of its vector "Asian citrus } \\
\text { psylla" }\end{array}$ & $\begin{array}{l}\text { Javed et al. (2007); } \\
\text { Bassanezi et al. }(2009)\end{array}$ \\
\hline Anthracnose & $\begin{array}{l}\text { Colletotrichum } \\
\text { gloeosporioides }\end{array}$ & $\begin{array}{l}\text { Branches, twigs show dieback symptoms; dark stains } \\
\text { appeared on fruit skin start postharvest decay }\end{array}$ & Preharvest spray of thiophanate methyl & $\begin{array}{l}\text { Adaskaveg (2008); } \\
\text { Ritenour et al. (2004) }\end{array}$ \\
\hline $\begin{array}{l}\text { Greasy spot } \\
\text { (rind blotch) }\end{array}$ & $\begin{array}{l}\text { Mycosphaerella } \\
\text { citri }\end{array}$ & $\begin{array}{l}\text { Between oil glands black tiny spots (pinpoint) latterly } \\
\text { transform into speck or blotch on fruit skin also called } \\
\text { pink pitting }\end{array}$ & $\begin{array}{l}\text { Copper based fungicides along with } \\
\text { petroleum oil sprays }\end{array}$ & $\begin{array}{l}\text { Futch (2011); Dewdney } \\
\text { (2019) }\end{array}$ \\
\hline Black spot & $\begin{array}{l}\text { Guignardia } \\
\text { citricarpa }\end{array}$ & $\begin{array}{l}\text { Fungal pathogen produces small, sunken, round, grey } \\
\text { centered necrotic lesions surrounded by tissue (green or } \\
\text { dark brown ring) on leaves, twigs and fruits. }\end{array}$ & $\begin{array}{l}\text { Appropriate fungicide application (up } \\
\text { to 5) can reduce disease in heavily } \\
\text { infected block }\end{array}$ & Futch (2011) \\
\hline
\end{tabular}
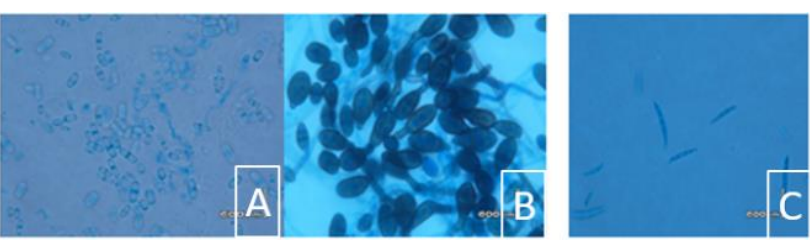

Fig. 4: Microscopic view of isolated fungal pathogens from blemished Kinnow fruit. $\mathrm{A}=E$. fawcetti, $\mathrm{B}=$ A. alternata and $\mathrm{C}$ $=F$. oxysporum

Source: Malik and Khan (2014)

cultivars especially grapefruit, lemons, tangerines, mandarin and their hybrids are affected by scab. It affects all plant parts including leaves, twigs and fruits and develops watery pustules on their surface (Gopal et al. 2014a). The lesions typically appear as small dots (semi-translucent) showing nipple like structures which expand up to three $\mathrm{mm}$ in diameter (Table 1). Old scabby lesions show water soaked, upward, honey colored symptoms and crack deeply as they age (Timmer et al. 2012). Scab reduces yield and up to 50\% worldwide market value of sweet orange and mandarin due to high incidence of blemishes on the fruit surface (Chung 2011). Citrus scab along with melanose have become the major cause of skin blemishes leading to high farmgate rejection in Kinnow mandarin (Malik and Khan 2014).

\section{Citrus melanose}

Citrus melanose is another destructive fungal disease caused by Diaporthe citri found worldwide in citrus groves. During humid weather, the fungus affects leaves and fruits of various citrus species during tissue growth and development. Melanose causing fungal pathogen damages the cosmetic quality of fruit but does not affect the pulp content. Grapefruit is most susceptible by melanose followed by mandarins, tangerines and oranges. It has varying symptoms including scab like smart netting on the external surface and showing different tear patterns such as tear drop, star and mud cake (Gopal et al. 2014b). Symptoms developed on fruit surface remain small, pustules may become prominent in the form of dropping tear like structure in the latter stage of development (Fig. 5). Situation of mud cake may occur just after petal fall or late bloom. At later stages, these symptoms may produce small spots known as flyspecks (Hardy and Donovan 2007). This is most common disease in Kinnow mandarin. Malik and Khan (2014) survey report of citrus growing areas of Pakistan revealed that about $77 \%$ citrus orchards were affected by melanose and scab; and among them, 15\% orchards showed level of high severity. Due to quality issue of rind blemishes caused by melanose, citrus fruits become unacceptable for exporters and consumers (Khalid et al. 2012b).

\section{Citrus canker}

Citrus canker is the most damaging bacterial disease widely distributed in citrus orchards around the globe. Canker is ranked a quarantine disease in various high-end international markets, and hence has trade restriction. Following a self-imposed restriction by industry, Pakistani Kinnow is not being exported to EU since 2015, due to canker issue, in the wake of likely rejection (Anonymous 2015). The affected fruit are sold at low price in local markets (Javed et al. 2007). It is believed that citrus canker originated from South East Asia and spread in limited duration in whole citrus genera (Fatima et al. 2019). 

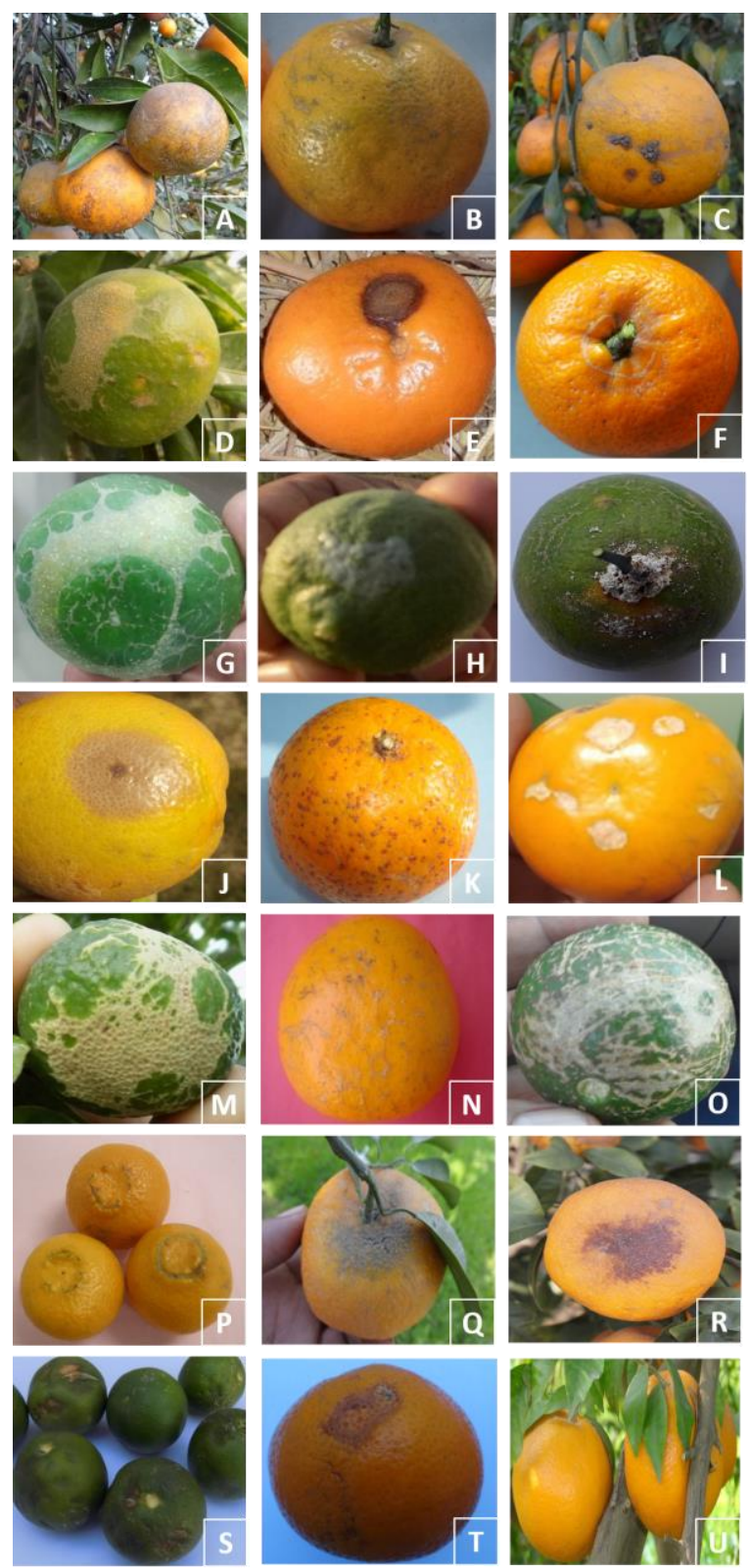

Fig. 5: Different types of rind blemishes on citrus fruit. Different letters represent specific blemish type. $\mathbf{A}=$ Citrus melanose, $\mathbf{B}=$ Citrus greening, $\mathbf{C}=$ Citrus canker, $\mathbf{D}=$ Citrus scab, $\mathbf{E}=$ Anthracnose, $\mathbf{F}=$ Thrips, $\mathbf{G}=$ Mites, $\mathbf{H}=$ Peel miner, $\mathbf{I}=$ Cottony cushion scale, $\mathbf{J}=$ Fruit fly, $\mathbf{K}=$ Red scale, $\mathbf{L}=$ Bush cricket feeding, $\mathrm{M}=$ Sucking insect web, $\mathrm{N}=$ Wind scratches, $\mathbf{O}=$ Dry branch rub, $\mathbf{P}=$ Stylar end deformity, $\mathbf{Q}=$ Stem end rind breakdown (Tarrer), $\mathbf{R}=$ Sun burn $\mathbf{S}=$ Hail injury, $\mathbf{T}=$ Oleocelosis, $\mathbf{U}=$ Blemish due to poor tree canopy management

Note: Some symptoms are combination of more than one causes, however these are often tagged with the predominate cause

Famous bacterium strain Xanthomonas campestris pv. citri is the most important causal agent of canker. It has short lifespan in the leaves and soil as well, but sometimes it prevails for long time in soil by developing microbial interaction especially with protozoa and show predatory effect. Warm humid and heavy rainfall, wind, and cloudy climate strongly promote citrus canker (Das 2003). Canker shows symptoms on all plant parts such as thorns, twigs, branches, leaves and fruits. Small raised and watery spots emerge on surface of plant parts initially and, as time passes, necrotic lesions become thickened, corky and brownish in color (Fig. 5). Infected petioles cause premature defoliation of leaves and deteriorate fruit quality due to the development of corky blemishes on the peel of fruit without disturbing internal quality.

\section{Citrus greening}

Citrus huanglongbing (HLB) or yellow dragon disease is commonly known as citrus greening. It is also a quarantine concern and affected fruit areas have trade restrictions. It is caused by bacterium Candidatus liberibacter asiaticus associated with restrictions of sieve tubes causing decline and unproductiveness of plants (Teixeira et al. 2005). Asian citrus psyllid (Diaphorina citri) and African citrus psyllid are considered as vector for its transmission to plant parts. Greening has been described as the most destructive disease worldwide. In 2004, Brazilian citrus orchards were badly affected and about three million trees were eliminated due to its severe attack (Bassanezi et al. 2009). Its main symptoms appear on leaves, twigs, and fruits. It may cause decline in tree life and fruit quality. Infected leaves show similar symptoms as leaves depicted in $\mathrm{Zn}$ deficiency i.e., interveinal chlorosis, yellowing of veins and sometimes premature defoliation. In severe condition, all parts of citrus plants may show twigs dieback and decay of roots (feeder and lateral), vigor decline and ultimate death of entire tree (Javed et al. 2007). Similarly, infected plants have small fruit size, low acid content, low soluble solid content (SSC), low soluble solid content/acidity ratio and poor peel color (Bassanezi et al. 2009) (Table 1).

\section{Other diseases}

A devastating disease 'anthracnose' (Colletotrichum gloeosporioides) in citrus orchards causes dieback of branches and twigs, leaf drop (premature), staining of fruit and postharvest decay. Infected twigs and leaves of citrus trees are covered with spores of typical fungus through which fungal pathogen spreads. Peres et al. (2004) described that Colletotrichum acutatum fungus causes fruit drop after full bloom of flowers, infects the flower petals of citrus by the development of orange to brown spots (blemishes) that ultimately induce the retention of calyces and abscission in fruitless. In a similar study, Adaskaveg (2008) revealed that the fungal attack of anthracnose may develop spotting (blemish) on peel tissues of various citrus cultivars such as grapefruit, valencia oranges, navel oranges and sometimes lemon.

'Encor' disease is reported in mandarin group where 
injury starts by the development of pre-harvest rind stains in few epidermal cells also known as initial spotted zones of rind which may develop as disorder of fruit. In later stages of stain development, disruption in rind of the fruit provides habitat for amoeboid like microorganisms resulting in the expressions of chlorotic disorders (Medeira et al. 2000; Maia et al. 2004). Similarly, citrus orchards especially grapefruit are susceptible to greasy spot (rind blotch) caused by Mycosphaerella citri, which also downgrades quality of fruit. The black tiny spots appear between the oil glands which later turn into blotch or speck commonly known as pink pitting. Around specks, the adjacent living cells remain green and normal color until exposure of ethylene for the purpose of de-greening.

Alternaria brown spot (ABS) produced by fungus $A$. alternata is among the important diseases observed in tangerines as well as its hybrids around the globe (Timmer et al. 2003; Peever et al. 2004). It produces adenylate cyclase toxin (ACT-toxin), which produces necrotic lesions on fruit and new foliage. Alternaria brown spot is more prevalent on dense trees with vigorous spring growth. Presently fungicides can be used to control ABS on vulnerable cultivars (Peres and Timmer 2006; Vicent et al. 2009).

Septoria spot is yet another disease of concern in citrus, which is caused by Septoria citri (Menge 2000). In most of citrus-producing countries, Septoria spot is normally considered as a disease of lesser importance, except for fruit produced for the fresh market because rind blemishes decrease aesthetic fruit quality. Overhead sprinkler irrigation favors Septoria spot in lemon orchards as well as brown spot appearance on susceptible tangerine cultivars, while under the canopy sprinkler irrigation causes Phytophthora infections on fruits. Symptoms of Septoria on fruit are small, round, light tan-colored lesions of 1-2 $\mathrm{mm}$ in diameter with a slender green border on the outer rind. These lesions become reddish to pale brown and have small black spots ( $S$. citri pycnidia) hardly observable to the naked eye as the fruit develops. During fruit storage or when frost occurs, these lesions may expand to $3-10 \mathrm{~mm}$ in diameter and combine to form brown-to-black sunken blotches. These lesions may enlarge to numerous centimeters in diameter and prolong to albedo and occasionally into the fruit segments. In severe cases, fruits drop prematurely and develop an off flavor.

Another fungal disease 'black spot' caused by Guignardia citricarpa is found in commercial citrus species except Tahiti lime. Its causal agent reproduces over infected fallen leaves in most suitable environment having high summer rainfall. Fungal pathogen produces small, sunken, round, grey centered necrotic lesions surrounded by tissue (green or dark brown ring) on leaves, twigs and fruits. Infected orchards may be susceptible for four to five months even after fruit set; fresh fruit is unacceptable for consumer and exporter in the market but can be used for processing (Futch 2011).

\section{Insects}

Several insect pests are responsible for damaging citrus groves. The insects potentially causing economic rind blemishes are peel miner, thrips, fruit fly, red scale and some other (Table 2).

\section{Peel miner}

Peel miner is considered a notorious blemish causing agent in insect's category. Its damage is visible on fruit rind due to skin feeding. Although, the apparent damage is cosmetic, the fruit is unacceptable for both national and international markets (Headrick 2004). Millar (2004) stated that the citrus leaf miner (Phyllocnistis citrella) is the most common insect in citrus growing regions of the world. Feeding damage caused by leaf miner also facilitates the development of citrus canker (Junior et al. 2006). All cultivars of citrus are affected by the damage of this insect; but grapefruit, tangerine and pummelo are the most susceptible (Fig. 5).

\section{Red scales}

Red scale (Aonidiella aurantii) (Hemiptra: Diaspididae) is also known as California red scale and has been reported as a serious pest of citrus. This insect, even in low population, causes economic injury by affecting the plant health as well as reducing the fruit marketability (Garcera et al. 2011; Alfaro et al. 2003; Vanaclocha et al. 2009) (Table 2). The larvae and adults of red scale are mobile, while other life stages are sessile and feed continuously on leaves, shoots, or fruits. Scales mainly suck cell sap from plant parts resulting in defoliation of leaves, loss of plant vigor and fruits drop (Anonymous 2004). In severe case of infestation of red scale, citrus tree loses its vigor and reduce production.

\section{Thrips}

Citrus groves all around the world are seriously affected by citrus thrips (Seirtothripscitri Moult), which causes significant economic loss to growers. Orphanids (1998) reported that Kelly's citrus thrip is most damaging specie to cosmetic quality of lemons and grapefruit as it develops scars around calyx of the fruit (Fig. 5). Thrips cause damage by feeding near calyx-end of the fruit and by developing a "halo" or ring having brownish tissues, which turn into grey colored scar (Table 2). Citrus thrips also cause injury to the flowers (Broughton and Lima 2002). Thrips feed in protected regions in the orchard, and thus the sheltered regions near the plants are their habitat. Thrips scars downgrade the quality of fruit and thus reduce fruit marketability.

\section{Mites}

Citrus red mites (Panonychus citri) are a common pest of evergreen or deciduous plants such as citrus, peach and pear. It interferes with the plant vigor and quality of fruit (Shi and Feng 2006). Primarily, young leaves are damaged on both 
Table 2: List of insect pest affecting the cosmetic quality of citrus along with possible control measures

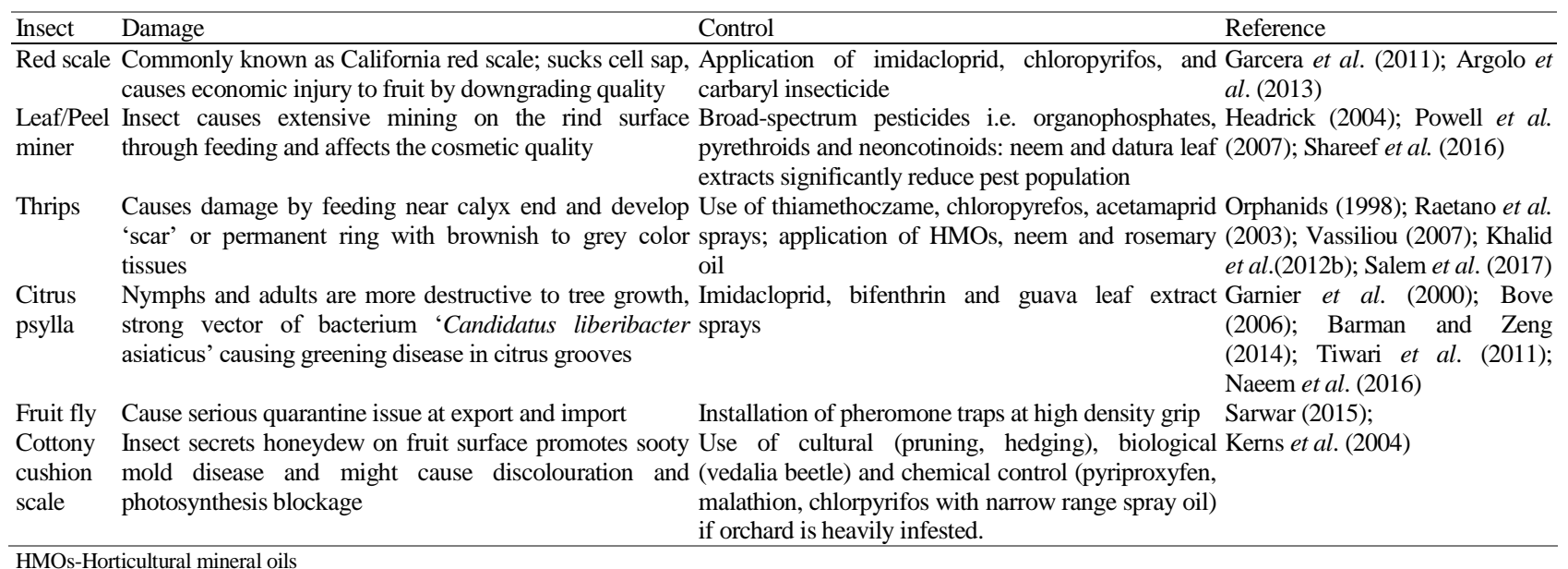

sides (upper, lower) and yellowing of leaves occurs (Gonzalez 2000). All parameters of fruit development are affected by mites; that also increases fruit drop percentage (Huan et al. 1992; Yang et al. 1994). Mites damage appears as rough web marks on fruit skin and their infestation is usually more in drier conditions, when temperature is high (Fig. 5).

\section{Citrus psylla}

Citrus psyllid (Diaphorina citri) is also known as Asian citrus psylla, which was first reported in Taiwan and then it spread throughout the tropical and subtropical Asian countries in a short time (Naeem et al. 2016). Citrus psylla at nymphs and adult stages is more destructive to tree growth and development and causes shoot dieback immediately by feeding (direct) on phloem tissues (Garnier et al. 2000). This insect is strong vector of bacteria (Candidatus liberibacter asiaticus) and potentially causes citrus greening or Huanglongbing (HLB) (Bove 2006). Halbert and Manjunath (2004) reported that affected plants can survive hardly up to 5 to 8 years and produce inferior quality fruit (color and taste).

\section{Citrus fruit fly}

Fruit fly is the most serious pest in all citrus growing tropical and sub-tropical regions having varying species of group Diptera: Tephritidae. This insect is active in fruit and vegetable gardens during or near the ripening stage (Cheng 2003; Umeh et al. 2004; Sarwar 2015). Fruit flies have annual life cycle or one-year generation that replicates multiple times in favorable temperature at around $22^{\circ} \mathrm{C}$. This is a pest of quarantine concern, and, depending on type of species in trading countries, its trade is subject to meeting specific market access protocols. These include cold quarantine and irradiation treatments. Sarwar (2015) reported that fruit fly infestation increases the possibility of rejection of horticultural commodities in trade (export and import) and needs more quarantine management at pre and postharvest level.

\section{Cottony cushion scale}

It is an infrequent pest found during humid conditions in regions of heavier soils and crowded plantation. It is a crawling insect with flight characteristics (male only) and moves from tree to tree through bird's feet and labor crews etc. Its female (reddish to brown in color) has distinguished egg sacs with grooved cottony white properties. After hatching eggs, the instars start moving along twigs, branches and rarely available on fruits. It sucks sap from different plant parts (leaves, twigs and branches) and reduces tree vigor and increases commercial fruit drop. It secretes honeydew on fruit surface which may discolor laterally and block photosynthesis and prone the fruit to attack by sooty mold (Kerns et al. 2004) (Fig. 5).

\section{Other insects}

Some other insects are also responsible for deteriorating cosmetic quality of citrus fruit. Bush cricket (false jumping type and dark brown in color) causes serious damage to peel by feeding on it (Fig. 5). Its serious infestation can cause pre-mature fruit drop, which is commercially unacceptable. Similarly, leaf footed bug (Leptoglossus phyllopus) (dark brown in color and $20 \mathrm{~mm}$ long) feeds on fruit by inserting mouthparts and damaging citrus peel which results in early breakdown of fruit color and sometimes causes serious fruit drop. Another insect 'green stink bug' is also known as plant bug (Nezara viridula) in citrus groves. It damages the external quality by piercing peel through sucking mouthpart and causes damage by the development of tiny brown spots in the albedo indicated as feeding sites (Futch 2011). Moreover, citrus mealy bug is also considered a destructive pest for citrus orchards. It starts feeding just after petal fall 
and initial fruit setting. Feeding of mealy bug on peel surface produces honeydew in abundance which leads to the development of cottony appearance and becomes a habitat for micro Lepidoptera to lay their eggs (Anonymous 2004).

Climate change is modifying the incidence, intensity and distribution of pests and diseases in citrus producing regions of the World. In a simulation model study, Aurambout et al. (2009) reported that increasing temperature due to climate change result in decrease in the Asiatic citrus psyllid (vector of greening disease) population in Northern Territory, Queensland and the northern part of Western Australia whereas increase in population will be observed in southern coastline of Australia. High temperature and relative humidity are conducive to disease and pest development which results in increased blemishes on the fruit (Davies 1997). Climate change favors leaf minor growth and survival as its generation time decreased with increase in temperature and showed no reduction in survival within 18 to $32^{\circ} \mathrm{C}$ (Chagas and Parra 2000). In colder environment leaf miner slows down development instead to enter diapause (Lim and Hoy 2006). Humid conditions in citrus producing areas caused by climate change also favor the red scale infestations (Nawaz et al. 2019) and high temperature favors oviposition of fruit fly (Nawaz et al. 2019) which results in more blemished fruit.

\section{Blemishes caused by abiotic factors}

Various groups of abiotic factors involved in development of fruit blemishes include environmental, physical, physiological, and nutritional. Some other unknown factors are also involved to cause stylar end deformity (SED) in Kinnow mandarin (Fig. 5).

\section{Environmental factors}

Wind: Citrus fruit can be scarred where twigs or thorns rub against the rind due to consistent or incidental winds. Rubbing of the skin of one fruit onto another object can cause scaring and discoloration of the rind (Albrigo 1976). Wind damage is the main cause of economic loss at pack house and export. Wind damage to fruit increases discard percentage in export; at least $10 \%$ reported in oranges (Valencia) and tangors (Ortanique and Ellendale) and reaches up to $40 \%$ in more susceptible varieties i.e., oranges ('Washington' navel) and Lemons (Lisbon) (Martinez 1995).

Wind scars on fruit occur when wind velocity exceeds $6.7 \mathrm{~m} \mathrm{~s}^{-1}\left(24 \mathrm{~km} \mathrm{~h}^{-1}\right)$ (Green 1968). Rind damage particularly occurs in early stages of fruit growth due to friction caused by leaves, twigs and sprouts (Roger 1988). It is initiated almost exclusively within 12 weeks after petal fall with significant fruit damage (95\%) (Freeman 1973). In early stages when fruit is of small size (less than $1 \mathrm{~cm}$ ), the rind damage mainly occurs due to rubbing of adjacent old hard leaves (small scale movement) to small petal-less fruitlets (Freeman 1973). The scratch caused by old leaves in early stages of fruit growth results in damage to the fruit skin, with the release of some oil on the fruit surface and after that tissues get repaired and become corky, turning fine creamy yellow. When fruit color development occurs, the mark becomes buff colored, but the final color depends upon on the chemical (particularly copper) used in spray program (Anonymous 2006). In mature fruit, rind damage could be associated with movement of branches, which hit the fruit (large scale movement) (Cataldo et al. 2013). This type of rind damage is primarily due to poor pruning practices followed in the orchard (Anonymous 2006).

\section{Sun burn}

Sunburn of citrus rind is also among major blemishes, causing significant economic loss. Fruits with sunburn necrosis typically have dark brown spots on the rind that is exposed to the sun; these spots appear as dark irregular areas. Sunburn injury on citrus fruit is mostly found on water stressed trees (Brown 2009) and predominantly on trees having poor vigor (Schrader et al. 2003). The leaves present on vigorous trees protect the fruit and branches from sun damage. However, in comparison with leaves, fruits are more prone to sunburn, mainly due to their lesser ability for using and/or dissipating solar radiation (Blanke and Lenz 1989). A combination of excessive visible light and temperatures cause sunburn injury in fruits (Generally, the fruits that grown on top, and on sun-side (south and southwest in northern hemisphere) in outer periphery are exposed to higher radiation and more prone to sun burn injury. Sunburn injury arises when reactive oxygen species are formed inside the fruit surface cells primarily because of high fruit surface temperature (Schrader et al. 2001, 2008). The free radicals are very reactive and cause a loss of membrane integrity due to electrolyte leakage and cell death (Wünsche et al. 2004). In citrus, sunburn is exaggerated by splitting of the oil glands into the flavedo, which causes injuries to underlying cells (Ketchie and Ballard 1968) (Fig. 5).

\section{Other environmental factors}

Hail can cause marks on exposed fruit surfaces. If hail occurs on young fruit, marks can become large and distinctive with fruit development (Fig. 5).

As a subtropical plant, citrus is mostly susceptible to frost and freeze. Oil glands in the fruit rind split due to low temperature, which results in oil leakage and injured the rind surface in the form of brown scares.

\section{Spray injury}

Citrus trees subjected to pesticide and fungicide sprays after fruit setting may cause spray injury to the fruits in extreme environmental conditions. It has been observed that the trees 
sprayed with faulty nozzle of sprayer / spray machine may get chemical concentrate on fruit skin which could cause severe rind injury upon exposure to sun.

\section{Physiological and Nutritional Factors}

In citrus fruit physiological disorders affect the flavedo, which lead to nasty marks on the rind surfaces resulting in unmarketable fruit (Cronje 2013). Fruit mineral contents are also important in determining external fruit quality (Cronje et al. 2011b). Important blemishes linked to physiological and nutritional causes are given below.

\section{Oleocellosis}

Oleocellosis causes blemishes on the citrus fruit and reduces its quality and value in the market (Lado et al. 2019) (Fig. 5 ). Moreover, damage caused by release of oil from oil glands can lead to increased decay (Krajewski and Pittaway 2002). Two mechanisms have been identified as causing this disorder. In the first mechanism, mechanical damage to the rind causes leakage of phytotoxic oils (terpenes) from oil glands into the flavedo (Fischer et al. 2009; Montero et al. 2012) damaging the cells and moving towards the fruit surface. In the second mechanism, the oil is translocated from the surface of a damaged fruit to an adjoining fruit during postharvest handling as this affects a larger area and can diffuse into the rind from the surface, leading to damage to epidermal and cortex cells in the flavedo (Knight et al. 2002). Pre-harvest oleocellosis develops on the tree because of various kinds of injuries such as insect damage or unfavorable environmental factors like wind or hail and bruising (Whiteside et al. 1988). Postharvest disorder occurs due to mishandling during harvest or transport to the packinghouse as well as during the packing process (Wild 1998). Weather conditions in the orchard and fruit ripeness stage influences the occurrence of oleocellosis (Alférez and Zacarias 2001). Fruit harvested after rain are more susceptible to oleocellosis occurrence (Santos and Oliveira 2004) (Table 3). This issue has been commonly observed in Kinnow mandarin harvested during rainy and foggy conditions.

\section{Rind breakdown (RBD)}

Vitor et al. (2000) reported that RBD disorder decreases cosmetic and commercial value of fruit without disturbing internal fruit quality. In Kinnow mandarin, a widely gown citrus cultivar in Pakistan, a typical stem end side rind breakdown (SERB), locally known as 'Tarrer' is observed at pre-harvest stage. A small crack appears in often drier/necrotic peel tissues at the shoulders mostly after foggy moist conditions (Malik and Khan 2014) (Fig. 5). In RBD, the hypodermal cells associated with an oil gland collapse possibly due to a physiological breakdown of cell membranes and organelles (Alférez et al. 2008) and the wound continuously extends and develops a necrotic area. Water potential changes and tension in the flavedo-albedo junction causes cellular disruption probably due to the dehydration at low RH (45\%) and later rehydration at high RH (95\%) which results in RBD (Cronje et al. 2011a). The disorder develops across the outer albedo and the inner flavedo, eventually approaching the epidermis. The RBD is different than oleocellosis chilling injury induced rind staining, stem end rind breakdown (SERB) and rind breakdown of 'Navelina' and 'Navelate' oranges. In oleocellosis, oil glands disrupt because of physical damage (Knight et al. 2002), whereas in RBD oil glands collapse due to physiological damage (aging) to cells. The RBD is different than chilling injury linked rind staining as RBD develops gradually in storage almost 21-35 days after harvest and not due to low temperature in storage (Lafuente and Zacarias 2006), as greater RBD occurred at $7.5^{\circ} \mathrm{C}$ than at $-0.5^{\circ} \mathrm{C}$ storage. The indicators of RBD of 'Nules Clementine' mandarin vary from SERB, rind breakdown of 'Navelina' and 'Navelate' oranges and rind staining, in the sense that the dark marks accompanied with a breakdown of oil gland are disseminated erratically above the surface of the fruit in a "leopard spot" design and are therefore not concerted at either the stem-end as in case of SERB (Albrigo 1972), or in the equatorial area as in the case of rind breakdown of 'Navelate' and 'Navelina' oranges (Alférez et al. 2003) and the injured cells do not extend to the epidermal cell sheet as observed in the rind breakdown / staining of 'Navel' orange (Agustí et al. 2001) (Table 3). Rootstock and postharvest water stress have also been implicated in rind breakdown as reported for 'Navelate' orange (Zacarias et al. 2001). 'Encore' mandarin is reported (Freeman 1976; Duarte and Guardiola 1995) to produce symptoms of chlorotic spots due to combination of several pre- and post-harvest factors such as climate, chemical, mechanical and chilling injury. The incidence of RBD increases with various postharvest treatments such as ethylene used for color development, a deferral in cooling, or extended storage, delay in washing, waxing, and packing (Hopkins and Mccornack 1961).

\section{Rind pitting or staining}

Pitting or staining disorders may become evident just one week after harvest during processing in the packinghouse, and its first symptoms may appear before shipment of the fruit. The first indication of pitting or staining of citrus fruit is the development of small, round depressions randomly scattered on the fruit surface. The dark "pitting" symptoms are often associated with collapsed oil gland and leakage of oil (Cronje 2013). The oxidation of oil glands results in dark brown lesions on the fruit (Alquézar et al. 2010). If the collapsed spot can develop in a continuous area it is referred to as staining whereas if the damaged rind forms clearly defined depressed and detached areas, it is termed as pitting. The development is aggravated by high temperatures 
Factors Affecting the Cosmetic Quality of Citrus / Intl J Agric Biol, Vol 25, No 2, 2021

Table 3: Citrus blemishes caused by physiological disorder and their causal factors

\begin{tabular}{|c|c|c|c|}
\hline S. No. & Physiological disorder & Casual factor & Reference \\
\hline \multicolumn{4}{|c|}{ Senescence related disorders } \\
\hline 1. & Rind breakdown & $\begin{array}{l}\text { Pre harvest: Fruit position in the canopy } \\
\text { Postharvest: Ethylene treatment. storage temperature and storage duration }\end{array}$ & $\begin{array}{l}\text { Van-Rensburg et al. } \\
\text { (2004): Khumalo (2006) }\end{array}$ \\
\hline 2. & Peteca Spot of Lemons & Occurs due to physiological breakdown (senescence) of the oil gland & Storey and Treeby (2002) \\
\hline \multicolumn{4}{|c|}{ Environmental conditions } \\
\hline 3. & Pitting or staining & Pre and postharvest change in temperature and $\mathrm{RH}$ & $\begin{array}{l}\text { Agustí et al. (1997); } \\
\text { Alférez et al. (2010). }\end{array}$ \\
\hline 4. & Stem end rind breakdown & $\begin{array}{l}\text { High amount of moisture loss from the flavedo due to high temperature and low RH (high } \\
\text { VPD) during harvest, packing, and cold storage. }\end{array}$ & Ritenour and Dou (2003) \\
\hline \multicolumn{4}{|c|}{ Mechanical damage } \\
\hline 5. & Oleocellosis & $\begin{array}{l}\text { Caused by mechanical damage to the rind due to mishandling during harvest or transport to } \\
\text { the packinghouse as well as during the packing process }\end{array}$ & Wild (1998) \\
\hline 6. & Zebra skin/horseshoe green & Caused by damaged during the packing process & Cronje (2007) \\
\hline 7. & $\begin{array}{l}\text { Blossom-End Clearing o } \\
\text { Grapefruit }\end{array}$ & $\begin{array}{l}\text { of The formation of a wet area on the fruit's surface is the result of internal bruising and juice } \\
\text { leakage out of the vesicles into the rind due to physical mishandling }\end{array}$ & Goell et al. (1988) \\
\hline 8. & Styler end deformity & Development of scar at styler end in the form of rind breakdown caused by unknown means & Malik and Khan (2014) \\
\hline
\end{tabular}

(Petracek et al. 1998) or occurs at ambient temperatures. The mechanism of rind pitting is not fully clear due to complexity of interactions between fruit and its adjacent environment (temperature and $\mathrm{RH}$ ) as well as pre and postharvest factors (waxing and modified atmosphere packaging). The more the level of dehydration in the fruit before and after harvest but before storage at high $\mathrm{RH}$, the more susceptible the fruit is to develop postharvest rind staining (Table 3).

\section{Pecteca spot}

Pecteca spot of lemon generally develops between harvest and cold storage. In this disorder oil glands collapse due to senescence (Storey and Treeby 2002; Cronje et al. 2014), leaking its contents into the surrounding tissues. This breakdown of the oil glands takes place in green and yellow fruit, but the depressed lesion is clearly observed in yellow fruit (Cronje 2007). Cold and moist conditions and sudden changes in day-night temperature adjacent to harvest have been linked with a higher prevalence of this disorder (Wild 1991; Torres-Leal et al. 2004). Rind maturity is also an important factor in the incidence of this disorder. Immature yellow colored fruit have more incidence of this disorder as compared to more mature fruit with 'silver' stage. The prevalence of peteca is more in early harvested fruit, and a dramatic reduction is observed with late harvested fruit (Cronje 2015). During processing, wax application, and brushing (Wild 1991); and during storage, $\mathrm{CO}_{2}$ exposure increases while ethylene treatment reduces its incidence (Cronje et al. 2014).

\section{Noxan}

The necrosis on flavedo surface of 'Shamouti'oranges is commonly called as noxan. It is a severe physiological rind discoloration in some parts of the world. This blemish is primarily observed in postharvest life of the fruit as surface depths on the flavedo, and progressively some depths develop in both size and number to form a necrotic region. Likewise, the analogous blemishes are mostly showing symptoms like SERB in oranges and the rind pitting of grapefruit (Grierson 1986). Petracek et al. (1998) defined an analogous blemish in grapefruit and 'Temple' oranges which is also associated to demolish oil glands, but unlike noxan, is caused by waxing. Ben-Yehoshua et al. (1983) revealed that the beneficial effects of sealing are related to the lessening of water stress of the fruit. Grierson (1986) also recommended that most blemishes of citrus rind are because of water stress. Cohen et al. (1979) have validated that noxan and brown pit, a similar blemish, are not produced by the bacterium Pseudomonas syringae but are physiological blemishes.

\section{Chilling injury}

Citrus, being the sub-tropical fruit, is susceptible to chilling injury during exposure to low temperature (Paull 1990). Generally, all citrus species can develop chilling injury in prolonged postharvest storage, but lemons and mandarins are comparatively more susceptible (Sala 1998). Lafuente et al. (2005) reported for 'Fortune' mandarin that chilling injury can be caused in fruit due to a combination of biochemical and physiological factors including genes transcript, carbohydrate composition, hormonal composition, changes in oxidative stress-associated and the phenylpropanoid metabolism processes, and alteration in lipid compounds of the fruit tissues. The symptoms of chilling injury include cold scald visible as a superficial grey or brown blemish, collapsed areas of dark brown color with irregular boundaries that is occasionally surrounded by brown 'halo'. Incidence of chilling injury in fruit with any other preexisting skin disorder is greater (Taverner et al. 2001). Citrus fruit affected with chilling injury are highly susceptible to decay and return little economic return (Maul et al. 2011).

\section{Nutritional Imbalance}

Deficiency or access of certain essential nutrients lead to 
different kind of rind blemishes in citrus.

\section{Copper}

Copper deficiency results in fruit splitting which starts from blossom end and appearance of dark reddish-brown marked areas of hardened gum on the fruit rind (Srivastava 2013).

\section{Boron}

Boron deficiency results in misshapen fruit with uneven surface and darkish colored spots appeared in white albedo of fruit (Rattanpal et al. 2017). Boron deficiency also causes peteca spot on lemon (Storey and Teeby 2002).

\section{Calcium}

Calcium improves rind strength and resistance to blemish such as rind pitting (Zaragoza et al. 1996) rind breakdown (Cronje et al. 2011a) and fruit creasing (Sallato et al. 2017). Abundance of calcium results in peteca spot on lemon (Storey and Teeby 2002).

\section{Magnesium}

Magnesium deficiency results in fruit creasing (Sallato et al. 2017).

\section{Management strategies for biotic based blemishes}

A great deal of research work on different aspects of rind blemishes management has been done in various citrus producing countries. Various interventions have been tested at pre-harvest level to resolve the issues and increase volume of marketable quality fruit, with key findings being summarized below.

\section{Use of synthetic fungicides}

Fungal infection resulting in scab and melanoses, and bacterial diseases (citrus greening and citrus canker) are the major source of disease-based blemishes in citrus (Ahmed 2005). Worldwide, one of the most popular and broadspectrum fungicides is Bordeaux mixture (copper sulfate pentahydrate and lime mixture). Since its discovery in 1885 , it is being extensively used for controlling various plant diseases (Lamichhane et al. 2018) including citrus crop. $\mathrm{Cu}$ is a micronutrient, when applied at higher concentrations acts as a broad-spectrum biocide due to its interaction with nucleic acids, disruption of enzyme active sites, interference with the energy transport system, and finally disintegrating the cell membranes (Fleming and Trevors 1989). However, all copper-based fungicides act as a contact material only and do not have a systemic action to penetrate plant tissues and kill pathogens. Therefore, these must be applied on fruits before disease occurs, to prevent infection, on a time coinciding with the conditions favorable for disease development (Kennelly et al. 2007). Although there are many formulas for preparing Bordeaux mixture, a ratio of 10-10-100 (10 pounds copper sulfate, 10 pounds lime, 100 gallons water) is more effective for many disease-causing pathogens (Broom and Donaldson 2010). Further, both spray concentration and spray volume are important for effective control of pathogens.

A number of other fungicides including Benomyl $\left(\right.$ Topsin $\mathrm{M}^{\circledR}$ ), Trifloxystrobin \& Tebuconazole (Nativo ${ }^{\circledR}$ ), Metiram Complex \& Pyraclostrobin (Cabriotop $\left.{ }^{\circledR}\right)$, Copper hydroxide $\left(\right.$ Champion $\left.^{\circledR}\right)$, Copper oxychloride $\left(\right.$ Coprus $\left.^{\circledR}\right)$ and Difenoconazole (Score ${ }^{\circledR}$ ) have been tested via in vitro evaluation where Benomyl, Trifloxystrobin \& Tebuconazole and Metiram Complex \& Pyraclostrobin ranked in the order of reducing the mycelial growth of $C$. gloeosporioides, A. alternate and $E$. fawcettii pathogens (Malik and Khan 2014). On the other hand, Trifloxystrobin, Azoxystrobin, Pyraclostrobin, Ferbam, Thiophanate-methyl (active ingredient of Topsin $\mathrm{M}$ fungicide) and copper fungicides, have been tested against citrus scab by spraying trees at various stages of fruit development (Chung 2011; Gopal et al. 2014a). Timmer et al. (2012) reported that copper-based fungicides had significant effect on grapefruit melanose at concentration of $907 \mathrm{~g}$. acre ${ }^{-1}$, and trees were sprayed at fruit size from $1 / 4$ to $1 / 2$ inch. Other citrus cultivars like oranges and tangerines need one or two fungicide applications. Likewise, Nativo (combination of Tebuconazole and Trifloxystrobin), a broad-spectrum systemic fungicide was tested at a commercial Kinnow' orchard at various concentrations and $0.6 \mathrm{~g}$. $\mathrm{L}^{-1}$ foliar application after fruit setting was found to significantly reduce incidence of melanose and scab diseases (Hasan et al. 2018).

Management of citrus canker is dependent on the amount of copper-based pesticide sprayed in epidemic areas. Behlau et al. (2017) reported that copper formulations containing copper hydroxide or cuprous oxide and copper oxychloride are commonly used by citrus growers for the eradication of canker. Crude streptomycine (100-1000 ppm) application after every 15 days and phytomycine (2500 $\mathrm{ppm}$ ) sprays are also reported as an effective remedy against canker causing pathogen (Javed et al. 2007). While copper salts are being used in several fungicides; copper chloride used as part and parcel of copper hydroxide and oxychloride production; during manufacturing, if not oxidized completely, can sustain in copper formulations up to $2 \%$ (Brodrick 1970). Copper salts are rapidly dissolved in water and turn into copper ions as soon as the product is added to spray tank. Copper with lead, cadmium and other heavy metals applied through spray can increase blemish percentage on fruit (Khalid et al. 2012a). On susceptible cultivars of citrus, foliar sprays of copper fungicides are recommended every 10-15 days during severe susceptibility of Alternaria brown spot (ABS). An integrated approach can lessen the threat of $\mathrm{ABS}$ infections and the disease severity 
(Timmer et al. 2003). Copper sprays in late fall or early winter to control brown rot are also beneficial against Septoria spot (Menge 2000). Dense planting is not recommended for vulnerable cultivars. Vulnerable cultivars should be frequently monitored to perceive the incidence and avoid epidemic outbreaks of the disease.

Topsin-M (thiophanate methyl) is another popular broad-spectrum fungicide and inhibits functioning of fungal tubule. Preharvest spray of thiophanate methyl consistently reduces postharvest diseases like anthracnose. It also affects incidence of stem-end-rot on harvested sunburst fruits (Ritenour et al. 2004). Zhang and Timmer (2007) tested several fungicides (benomyl, azoxystrobin, fludioxonil, thiophanate methyl and pyraclostrobin) as preharvest strategy for the control of postharvest diseases (anthracnose and stem-end rot) on citrus cultivars. Topsin-M was found more effective for the control of postharvest green mould in Navel oranges.

It can be surmised that fungicides have wide range of effects in the management of plant diseases related to fungus and related pathogens. Globally, various fungicides are being used on regular basis to prevent the crops from losses. In order to obtain the best result, their applications need to be optimized due to risk of resistance development, fungicide efficacy, environmental concerns, pesticide residues and impact on beneficial organisms, etc. (RebollarAlviter and Nita 2011).

\section{Effect of synthetic insecticides}

Citrus orchards can be a habitat for good and bad bugs which may perform activities beneficial for the plant and fruit growth and development, harm to the plant, as well as damage the fruit quality. Peel miner, red scales, thrips, fruit fly and mites are the potential insects of concern as well as main causal agents for fruit blemishes (Futch 2011; Mazhar 2007; Mazhar et al. 2007). Mealy bug and citrus psylla (Khalid et al. 2012b) also cause direct or indirect damage. The suitable strategy of insects control is the right choice and timely application of pesticides against the type (sucking or chewing) of insects (Khalid et al. 2012b).

Many growers have adopted broad spectrum insecticides such as organophosphates, pyrethroids and neoncotinoids. Broad-spectrum insecticides are generally inexpensive in the market, but these can also kill beneficial pests just due to their uneven application (Desneux et al. 2007; Lu et al. 2012). Zhang et al. (2012) reported the emerging class of pesticide 'Neonicotinoid' having novel mode of action commonly used by orchard owners, because they have antagonistic effect on insect nicotinic receptors which ultimately affect their transmission way of nervous system. This group of insecticides contains popular insecticides like Imidacloprid, Nitenpyram, Thiamethoxam, Acetamaprid, Chlothianidin, Thiacloprid and Imidaclothiz which are being marketed with various trade names. TalebiJahromi (2007) described Imidacloprid as a type of systemic insecticide which acts as neurotoxin and can be effective in every type of pest. Imidacloprid concentrations at lower levels were found to be effective for the management of several insect pests of vegetables and fruit plants (Rakhshani 2002; Sabar 2011). Likewise, Thiamethoxam is mostly used for the control of sucking type of insects (aphids, thrips, whiteflies, lepidoptera and coleopteran species) and certain chewing pests. Presently, thiamethoxam is one of the most effective chemicals used as pesticide of varied concentrations. It has contact and systemic mode of action and can be applied as soil, foliar, and used as seed treatments in agriculture crops (Karmakar and Kulshrestha 2009).

Previously, insect specific insecticidal control was being used. For example, imidacloprid (Argolo et al. 2013), chloropyrifos (Garcera et al. 2011) and carbaryl insecticide (trade name Sevin) used against California red scale which causes most economic cosmetic injury to the citrus fruit (Walker et al. 1999). Similarly, Minecto Pro (cyantraniliprole, abamectin), Chlorpyriphos and Acetamiprid sprays were found most effective remedy against citrus thrips (Vassiliou 2007; Grafton-Cardwell and Doria 2020). As discussed earlier, leaf miner or peel miner is a serious pest in citrus orchards, almost all major groups of broad-spectrum insecticides including organophosphates, pyrethroids and neoncotinoids have been tested as their control measure (Powell et al. 2007). Moreover, Asian citrus psylla are found more destructive pest in citrus groves that causes shoot dieback and stunted plant growth due to the direct feeding of nymphs and adults. It also serves as a vector for causal bacteria which result in citrus greening disease (Bove 2006), thus disease infected plants bear inferior quality of fruit (Halbert and Manjunath 2004). Tiwari et al. (2011) reported that use of imidacloprid chemical spray has become common trend in growers against citrus psylla and other sucking type of insects because of its effectiveness. Naeem et al. (2016) performed a comprehensive study in different districts of Punjab, Pakistan and tested seven insecticides including imidacloprid, acetamiprid, bifenthrin, thiamethoxam and nitenpyram. Results depicted that bifenthrin showed better control as compared to others regarding the efficacy and pesticide resistance.

Various management strategies have been suggested at pre-harvest and postharvest stages for the control of scales. At preharvest level, various insecticide groups were tested including organophosphates and neonicotinoid (imidacloprid) which significantly decreased the insect pest population (Garcera et al. 2011). Walker et al. (1999) reported reduction of scales population in packing house by applying high pressure water sprays that physically detached the scales.

\section{Use of plant extracts and alternative of chemicals}

Physiological peel spots or defects are the most critical factors affecting external appearance of fruit of various citrus cultivars that cause economic loss to industry 
worldwide (Alférez et al. 2003). Plant extracts are being used as substitute of synthetic chemicals against various plant diseases because of high anti-microbial and anti-fungal properties. Different plant parts have abundant reserves of phytochemicals including phenolics, flavonoids, flavanoles showing inhibitory mode of action against various pathogens (Farooq et al. 2018). Disease severity of citrus scab is reported to have been significantly reduced in lemon fruits when trees were sprayed with allamanda leaf extract and showed similar results to target fungicides (Siddiquee et al. 2011). Lemon grass and parthenium extracts (ethanolic) were tested in lab conditions against fungal pathogen of scab, both botanicals showed minimum fungal growth and their application at field can be tried as a best remedy against fungal diseases (Rehman et al. 2016). Various plant extracts from different plant parts i.e., Hibiscus subdariffa Linn. (dry flower), Psidium guajava Linn. (leaves), Punica granatum Linn. (dry fruit skin), Spondias pinnata (Linn.f.) Kurz (fresh leaves), and Tamarindus indica Linn (fruit pulp) were evaluated against Xanthomonas bacterium (causing citrus canker) on lime plants in the green house as well as in the field. In the green house, the fruit pulp of Tamarindus indica significantly showed least disease incidence (48\%) as compared to control (100\%), while in the field, $T$. indica depicted $3.59 \%$ disease incidence compared to control $(9.46 \%)$ in the field (Leksomboon et al. 2001).

Natural plant extracts are available with wide range of action characteristics i.e., insecticidal, repellence to pests, antifeedant effects, toxicity to various pests and nematodes (Prakash and Rao 1997). Various types of plant extracts such as neem, garlic, ginger, tobacco, syringe, Eve's apple, lilac and Kappettiya from different plant parts (leaves, seeds, fruits, peels) have been utilized as green pesticides for pest control (Rehman et al. 2016). Vasquez et al. (2016) reported the effect of acetogenins available in the seed extract of Annona mucosa Jacq. on citrus red mites and showed high mortality rate of red mite females after varying times of exposure to seed oil. This was the first report on acetogenins as miticide which can be commercialized at pre-harvest stage on domestic level due to low cost in small areas. Similarly, high concentrations of guava leaf extract were tested in the laboratory against adult psyllids both in the cage and Yolfactometer tests. Guava leaf extract significantly reduced (44.2 and 50\%) the adult psyllids landing on citrus shoots sprayed with $10,000 \mathrm{mg}$. $\mathrm{L}^{-1}$ followed by $5,000 \mathrm{mg}$. L $\mathrm{L}^{-1}$ respectively (Barman and Zeng 2014). Moreover, neem and rosemary oil were also identified as a good repellent of thrips in citrus orchards, reduced rind scaring and improved the cosmetic quality of fruit (Salem et al. 2017). In another study, selected botanicals including leaf extracts of neem (Azadirachta indica A. Juss), datura (Datura stramonium L.) and peel extracts of lime (Citrus aurantiifolia Swingle), and kurtuma (Citrullus colocynthis L.) were tested against the control of leaf miner. Results revealed that population of leaf miner significantly reduced by $12 \%$ through the application of $30 \%$ neem and datura leaf extracts (Shareef et al. 2016).
While plant extracts show potential in controlling various insects/pests, the main limitation remains their availability and commercial viability.

\section{Horticultural mineral oils}

Horticultural mineral oils (HMOs) are the most effective alternative to synthetic chemicals for the control of blemish causing insect pests and diseases since they are non-toxic and have little or no side effects (Nile et al. 2019). HMO assessed in agroclimatic conditions of district Sargodha, Pakistan revealed that, foliar application of 1.5\% HMO along with pruning significantly reduced the population of mites, psylla, aphid, leaf miner and citrus mealy bugs in Kinnow mandarin, and increased proportion of A-grade fruits, while no sign of phytotoxicity was observed (Khalid 2013; Jahangir 2018). Time of spray application is crucial factor to achieve best results as according to Tree-Fruit Environment profile (TFE) (Fig. 2) insect pest active period and development of blemishes on citrus fruit is from March to May (Khalid et al. 2012b). Results from study in Vietnam suggests that, application of HMO is highly effective in limiting the population of red mites, citrus rust mites, citrus mealy bug and red scales in sweet oranges (Nguyen et al. 2001). Reports from an IPM program in China on citrus claimed that, major foliage and fruit insect pest and diseases like citrus red mite, citrus rust mite, armoured scales, sooty mould were effectively controlled by using low concentrations of HMO (Huang et al. 2001). Spread of Huanglongbing in citrus (Citrus greening) was observed in Malaysia and it was revealed that the infection was significantly reduced $(11.4 \%)$ in HMO treated plots as compared to untreated control plot $(42.2 \%)$ (Leong et al. 2012). Certain fungal diseases (greasy spots, melanoses, alternaria brown spots) on fruit are very common in Florida citrus groves and the growers use different HMO concentrations mixed with copper formulations, which proved to be very effective (Roberts and Timmer 2001).

\section{Use of Biological control agents}

Biological control is a potential alternative to chemical methods for insect pest and disease management, but its impact and level of use globally remains modest and inconsistent (Gurr and You 2016). But at the same time, this strategy along with other management techniques have been successfully executed around the globe, various multinational companies provide commercially reared insects for biological control. Likewise, the Chinese citrus growers have been using predatory arthropods since hundreds of years ago and about 109 natural enemies reported against different citrus pests in China (Niu et al. 2014).

\section{Other technologies}

Organic mulching beneath citrus trees potentially increase 
the population of predatory mites which feed on Kellys citrus thrips (Pezothrips kellyanus) pupae which is important pest of citrus in New Zealand (Jamieson and Stevens 2006). Similarly, population of citrus red mites (CRM) is highly associated with the presence of predatory mites and other natural enemies including Ladybirds, Stethorus spp. and Halmus chalices in citrus orchards (Jamieson et al. 2005).

Studies from Spain revealed that use of sticky barrier in citrus was effective and economical in controlling population of ants in tree canopy (Blasco et al. 2010). James (1991) revealed that installation of sticky band around tree trunk significantly prevented the oviposition by the curculionid Asynonychus cervinus [Pantomorus cervinus] on Valencia orange fruit. However, a study on sticky bands and colored tapes did not show significant effect in insect management in Kinnow mandarin orchard in Sargodha, Pakistan (Khalid 2013).

\section{Management strategies for abiotic based blemishes}

Cultural practices in orchards such as pruning, fruit thinning, irrigation, fertilization, weed control etc. contribute to better plant growth and development and fruit quality. For fruiting trees, pruning is compulsory operation to prolong bearing age, quality fruit production, reducing blemishes and enhance effectiveness of other cultural practices like spraying etc. (Smith 1999). Kinnow mandarin when pruned properly gives higher yield, with more fruit weight and attractive orange color. In case of light or no pruning in Kinnow trees; light cannot reach in crowded groves and poor-quality fruit is produced (Ahmad et al. 2006; Khalid 2013). Similarly, Green (1968) and Gravina et al. (2011) revealed that wind velocity not to exceed $24 \mathrm{~km} . \mathrm{h}^{-}$ ${ }^{1}\left(6.7 \mathrm{~m} . \mathrm{s}^{-1}\right)$ in fruits and $5 \mathrm{~m} . \mathrm{s}^{-1}$ in citrus crop, otherwise wind damage is produced on fruit peel. Different trees of erect stem nature including Casuarinas, Eucalypts, Cypress, Poplars, Pines, and Alders can be planted as natural wind breaks for citrus orchards (Owen-Turner and Hardy 2006). Likewise, wind borne blemishes can be reduced by using semi-porous artificial windbreak nets $(5 \mathrm{~cm}$ by $10 \mathrm{~cm}$ mesh) in the citrus orchards (Gravina et al. 2011).

Reduction of temperature and direct sun contact can decrease the risk of sunburn on fruit (Smart and Sinclair 1976). Kaolin-based particle films, due to their reflective nature of the particles and having the ability to modify the microenvironment of the plant canopy, can reduce heat and ultraviolet stress in horticultural crops and can reduce sunburn damage (Glenn 2012). After concluding trials in Egypt, El-Tanany et al. (2019), recommended spray of kaolin at $4 \%$ or Glycine betaine at $50 \mathrm{~m} M$ three times during summer months (May, June and July) as an effective remedy to reduce fruit sunburn damage, improvement of yield and fruit quality of Balady mandarin trees. Sunburn on citrus fruits can also be reduced on commercial scale by reducing water stress through optimal irrigation during critical periods by using shade nets (Smit 2007) and by applying kaolin particle film technology (Table 4).

Climatic conditions of a region have a significant effect on quality of fruit which is more visible than any other factor such as site (cultural practices), soil and the genetic characters. Citrus cultivars (mandarins, oranges, lemons and limes) are suitable to specific regions with variable fruit quality (Albrigo 2004). A single cultivar 'Navel orange' grown in two different states (California and Florida) of U.S.A. produced different quality characters (Ladaniya 2008). So, only locally tested management strategies should be recommended to reduce the incidence of blemishes caused due to abiotic factors.

\section{Management strategies for physiological blemishes}

For control of oleocellosis, fruit should not be harvested in wet conditions, such as after rainfall in the harvest period, as this leads to more turgid oil glands and results in higher incidence of this disorder. It is also recommended not to harvest sensitive cultivars early in the morning but to wait until the ambient temperature has increased, which leads to some moisture loss from the rind and therefore a less turgid oil gland.

To control peteca spot development, packing-line speed should be as slow as possible, and wax applied to allow for enough $\mathrm{CO}_{2}$ exchange from the fruit to the surroundings. Noxan incidence on 'Shamouti' orange have been significantly reduced by different postharvest treatments like individual seal-packaging, packaging of fruit with plastic liners or in plastic bags or even by briefly keeping the fruit in a saturated environment (Ben-Yehoshua et al. 2001).

Chilling injury can be managed by gradually exposing the fruit to low temperature regimes through the desired storage duration (Taverner et al. 2001). Generally, if citrus fruit is required to be stored for longer duration then initial holding of fruit at $10^{\circ} \mathrm{C}$ for 2 to 3 weeks followed by holding the fruit at $5^{\circ} \mathrm{C}$ for up to three weeks can be helpful. In case the fruit is required to be held below $3^{\circ} \mathrm{C}$ to meet the quarantine requirements, then the fruit should be marketed in six weeks from the time of harvest.

\section{Postharvest technologies for blemish detection}

Worldwide, most of the pack-houses sort out blemished fruit visually by employing labor, primarily at two stages (before washing and then before packing) of processing. However, various modern postharvest technologies including nearinfrared (NIR), ultraviolet (UV) and ultraviolet fluorescence (UVF), hyperspectral imaging (HI) and laser backscattering imaging (LBI) have been evolved and tested for blemish detection of citrus fruits with fast and accurate assessment (Blasco et al. 2007; Lorente et al. 2013; Zhang et al. 2018). Commercial model for blemished based grading and sorting, are an option with greater efficiency and quality assurance 
Table 4: Sunburn control measures in citrus groves

\begin{tabular}{|c|c|c|c|c|c|}
\hline S. No. & Crop & Country & Treatment & Application rate & Results $\quad$ Reference \\
\hline 1. & $\begin{array}{l}\text { Balady } \\
\text { mandarin }\end{array}$ & Egypt & $\begin{array}{l}\text { Screen Duo }{ }^{\circledR} \\
\text { and Surround } \\
\circledR\end{array}$ & $\begin{array}{l}\text { Screen Duo } ₫(1.25 \mathrm{~kg} / 100 \mathrm{~L} \text { of water }) \\
\text { single application } \\
\text { Screen Duo } ₫(1.25 \mathrm{~kg} / 100 \mathrm{~L} \text { of water }) \\
\text { double application } \\
\text { Surround } ₫ 3 \% \\
\text { Surround } ₫ 6 \% \\
\text { In both season all treatments were applied } \\
\text { in mid-June whereas Screen Duo } \AA \text { was } \\
\text { applied in mid-June and first July. }\end{array}$ & 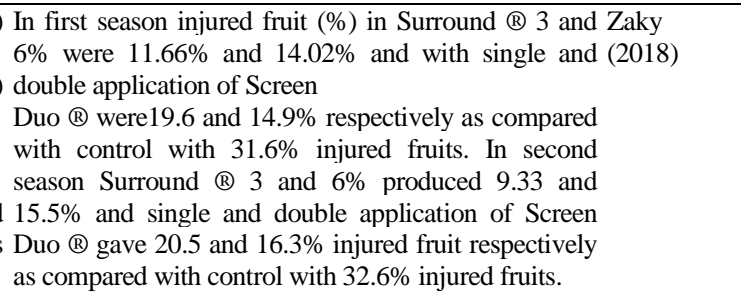 \\
\hline 2. & $\begin{array}{l}\text { 'Murcott' } \\
\text { Tangor }\end{array}$ & Taiwan & $\begin{array}{l}\text { White paper } \\
\text { bags, calcium } \\
\text { carbonate and } \\
\text { shade nets }\end{array}$ & $\begin{array}{l}\text { White paper bags }(27.8 \times 15.8 \mathrm{~cm}) \text {, } \\
\text { calcium carbonate }(3 \%) \text { three applications } \\
\text { from } 22 \text { July to } 28 \text { September, or shade } \\
\text { nets (white with } 20 \% \text {, green with } 30 \% \text { and } \\
\text { black with } 50 \% \text { shading rate) installed } 50 \\
\mathrm{~cm} \text { above the citrus trees. }\end{array}$ & $\begin{array}{l}\text { In white paper bags and shade nets treated fruit Tsai et al. } \\
\text { sunscald was } 0 \% \text { and in calcium carbonated treated (2013) } \\
\text { fruit } 4.4 \% \text { as compared with control with } 13.6 \% \text { sun } \\
\text { burn injury. }\end{array}$ \\
\hline 3. & $\begin{array}{l}\text { 'Miho } \\
\text { Wase' } \\
\text { Satsuma } \\
\text { mandarin }\end{array}$ & $\begin{array}{l}\text { South } \\
\text { Africa. }\end{array}$ & $\begin{array}{l}\text { Screen }^{\mathrm{TM}}, \\
\text { Vapor Gard®, } \\
\text { Silicon, } \\
\text { Nontox } \\
\text { Silica® and } \\
\text { Raynox }^{\mathrm{TM}}\end{array}$ & $\begin{array}{l}\text { Screen }{ }^{\mathrm{TM}}(2.5 \mathrm{~kg} / 100 \mathrm{~L} \text { water }) \text {, Vapor } \\
\text { Gard }{ }^{\circledR} \text { Silicon }(1 \mathrm{~L} / 100 \mathrm{~L} \text { water }) \text {, Nontox } \\
\text { Silica }{ }^{\circledR}(200 \mathrm{~mL} \text { concentrate/100 L water }) \\
\text { and Raynox }{ }^{\mathrm{TM}}(2.5 \mathrm{~L} / 100 \mathrm{~L} \text { water }) \text {. } \\
\text { Treatments were applied on } 10 \text { and } 21 \\
\text { December } 2009 \text { and on } 27^{\text {th }} \text { January } 2010\end{array}$ & $\begin{array}{l}\text { Screen }{ }^{\mathrm{TM}} \text { reduced the sunburn incidence by } 50 \% \text {, by Verreynne } \\
\text { reducing leaf and fruit temperature. Vapor Gard® and Merwe } \\
\text { increased fruit temperature, and increased sunburn (2011) } \\
\text { incidence by } 16 \% \text { while, other treatments had no } \\
\text { effect on sunburn incidence. }\end{array}$ \\
\hline 4. & 'Ponkan' & & White netting & $\begin{array}{l}\text { White nylon net with } 20 \% \text { shading rate } \\
\text { installed } 100 \mathrm{~cm} \text { above the tree from } \\
\text { August to end of October. }\end{array}$ & $\begin{array}{l}\text { In } 2009 \text { season low sunburn injury }(3.4 \%) \text { was Lee et al. } \\
\text { observed in September and October months as (2015) } \\
\text { compared with control with } 8.3 \text { and } 8.5 \% \text { sunburn } \\
\text { injury during September and October respectively. } \\
\text { During } 2010 \text { season } 2.94 \text { and } 3.04 \% \text { sunburn injury } \\
\text { was recorded in September and October respectively } \\
\text { as compared with control with } 9.15 \text { and } 9.45 \% \\
\text { sunburn injury in September and October respectively. }\end{array}$ \\
\hline
\end{tabular}

but their high cost is prohibitive in adoption especially in developing countries and small-scale packing operations.

\section{Integrated approach to reduce rind blemishes}

Internationally, huge resources are spent for managing causal organisms of citrus peel blemishes (Agostini et al. 2003; Maia et al. 2004) and to improve fruit quality. Experimental success does not always lead to commercial solution, since the field conditions and complexity of issues greatly varies. Hence, an integrated approach tested under local condition can help resolve the issue. Previously, different researchers (Ahmed 2005; Mazhar 2007, Mazhar et al. 2007; Khalid 2013; Hasan 2018; Waqas 2019; Malik et al. 2019) made extensive studies and tested several interventions (pruning, pest and disease management, HMOs, nutrition, new chemistry fruit fly baits etc.) to reduce rind blemishes in Kinnow mandarin. As a result, significant improvement was reported in fruit cosmetic quality and final pack out (Khalid et al. 2012a; Hasan 2018; Malik et al. 2019). Main strategy was to prevent, inhibit or lessen the incidence and severity of issues, using judicious tree pruning (major pruning immediately after harvest followed by removal of unwanted growth and water sprouts during season) and orchard floor sanitation (removal of weeds, pruned material, dead diseased branches, fallen fruits) for reducing disease inoculum and pest hibernation, and timely application of most effective fungicides/insecticides. Among the copper-based fungicides,
'Kocide' (2.5 mg L ${ }^{-1}$ ) performed significantly better, beside Bordeaux mixture, which has always been a good choice for fungal and bacterial disease complex suppression, while Nativo (Trifloxystrobin \& Tebuconazole) $0.6 \mathrm{mg} \mathrm{L}^{-1}$ outclassed others as broad-spectrum (preventive and curative) fungicide. Among insecticides, Confidor $1.5 \mathrm{~mL} \mathrm{~L}^{-1}$ and HMO $\left(1.5 \mathrm{~mL} \mathrm{~L}^{-1}\right)$ sprays produced best results, to minimize disease incidence and insect pest control (Khalid et al. 2012b; Hasan 2018; Malik et al. 2019). For fruit fly, change of geometry by installing six pheromone traps in a row per acre length significantly improved male trapping and control (Malik et al. 2018). Overall, the integrated approach significantly reduced rind blemishes and increased proportion of A-grade fruit (Hasan 2018; Waqas 2019; Malik et al. 2019).

\section{Conclusion}

Citrus rind blemishes are caused by several biotic and a biotic factor, including diseases, insect pest and various physiological and nutritional nature, resulting in high fruit rejection and heavy economic losses to growers. The prevalence of diseases and insect pest varies depending upon cultural practices, climatic conditions, and species etc. However, now a days, diseases of main concern causing rind blemishes in citrus are melanoses, scab, and citrus canker, Pathogens related to melanose and scab are most active during initial fruit development when environmental 
conditions are mild (temp. average $22-27^{\circ} \mathrm{C}$ and wetness for $>80 \mathrm{~h}$ per week) (Agostini et al. 2003). Symptom based identification sometime become challenging due to the presence of more than one disease compounded with other factors (insect or wind etc.). For correct identification of the pathogen, appropriate sampling time and techniques are critical, as in some case while the symptoms are still there on rejected fruit, the fungus was not isolated. Hence, improved sampling technique and appropriate time are necessary for proper disease diagnosis.

Various research studies and reject fruit analysis at commercial facilities, show that thrips, mites and scales, are the most common insects causing cosmetic damage to citrus fruit. Thrips infestation starts at the earliest stage, from petal fall to the time fruit attains $4 \mathrm{~cm}$ in diameter (Arpaia and Morse 1991). Mites are prevalent at later stage of fruit development (May to September) when temperature is high (Fig. 2). Among other insects, scale infestation is more in dense orchards with high humidity. Leaf miner is active during citrus flushing period, but it causes damage at early stage when fruit skin is soft. Identification of blemishes due to mites become difficult in the presence of wind blemishes, as they get mixed easily, and a closer examination need using magnifying glass.

Among the abiotic factors, environment related windborne blemishes, and sun burn are the most common at production level. Olecellosis is linked to physical pressure, and become an issue when fruit is harvested under rainy/moist conditions as well as due to mishandling during postharvest stages. Stylar End Deformity (SER), is a new type of blemish found in Kinnow mandarin, in which some tissues at the stylar end become raised as ring like structure due to some unknown cause. Chilling injury associated blemishes may also develop in some citrus species when stored at sub-optimal temperature for longer duration.

Managing citrus rind blemishes is a major challenge all over the world, and an integrated approach will be the major influencer for producing better quality citrus fruit. Tree pruning and cleaning plays a key role in reducing disease inoculum, by improving aeration and better spray penetration within canopy of tree. More fungal and scale linked blemishes at lower canopy draws attention to better skirting and spray coverage for controlling fungal infections and insect pest population. Understanding the issue, implementing an appropriate monitoring system and timing of control measures are the key for successful management. Diseases like melanose and scab appear on young fruits. Likewise, thrips cause damage at early fruit stage, while mites are problem during summer. Avoid the application of excessive amount of nitrogenous fertilizers and/or frequent heavy irrigation as both increase diseases incidence. Use drip irrigation to reduce fruit diseases. Use of recommended insecticides and fungicides at optimum dose at correct time, especially focussing during initial 8-12 weeks of fruit development, with due consideration to biological alternatives, can effectively reduce the disease and insect pest pressure in the orchard ultimately leading to reduced fruit blemishes and the farm gate rejection. Copper sprays in late fall or early winter to control fruit brown rot caused by Phytophthora citrophthora are also effective against Septoria spot. Incorporation of HMOs in spray programs helps in managing insects and diseases as well as avoiding resistance development. Application of best practices in harvest and postharvest can help manage the incidence of blemishes (Oleocellosis, rind breakdown, bruises, chilling etc.) during postharvest supply chain. In order to avoid cross-contamination of bacterial and fungal diseases, fruit bins, pruning scissors and harvest clippers, need to be cleaned and sanitized regularly (Malik and Khan 2014). Nonetheless, research at grower's fields in different citrus growing regions to test and customize integrated technology would be the prudent approach.

\section{Future research directions}

This review clearly shows significant advancements made in different aspects of citrus fruit blemishes and their management to improve cosmetic quality of fruit. However, still work is required to address the unresolved issues and challenges. Research is required on evaluating the impact of climate change on the dynamics of insect pest and disease pressure and their resistance, in different citrus growing regions of the world. Research is also needed to produce blemish free fruit production under high density small tree framework. Research on new-chemistry insecticides, IGRs, fungicides with low health and environmental risks will remain a high priority area. Further, there is need for comprehensive studies on the causes and control measures of some rind blemishes still not understood e.g., stylar end deformity (SED) and stem end rind breakdown (SERB) disorders in Kinnow mandarin which are becoming critical problem in citrus groves. In future, more research is needed to develop low cost technology of blemished based fruit sorting for better efficiency, and quality at packhouses. Finally, since in an agriculture eco-system all fruits on tree in an orchard can never be $100 \%$ blemish free, therefore research is also needed to change perception of the consumers about the quality of blemished fruit and improve its acceptability, highlighting the relevant aspects like blemished fruit does not mean always poor internal quality, impact of fruit rejection based on blemishes accounts food loss and waste etc.

\section{Acknowledgements}

This review is dedicated to the Leo Gene Albrigo (Emeritus Professor, Ph.D., citriculture, UF/IFAS Citrus REC, Lake Alfred, 33850) (August 24, 1940-February 8, 2020), who made significant contributions toward citrus industry by his work on peel morphology and fruit blemishes caused by various biotic and abiotic factors. Authors gratefully thank Endowment Fund Secretariat (EFS), University of 
Agriculture, Faisalabad for providing financial assistance for the project entitled "Reducing Rind Blemishes in Kinnow Mandarin for Improving Cosmetic Quality and Farm Gate Income" for technology transfer and betterment of citrus grower's livelihood. The authors also thank $\mathrm{Dr}$ Andrew Macnish of Department of Agriculture and Fisheries Queensland for critical review and advice provided for improvement of the manuscript.

\section{Author Contributions}

AUM identified the information gap and conceived the idea; outlined the project contents; writing, editing and reviewing the original draft; final approval for submission; MUH, SK and MSM collected, compiled and analyzed the information, editing and reviewing the original draft; final preparation for submission. All other authors equally contributed in providing critical feedback by sharing data and pictures, commenting, revising and finalizing the manuscript as a quality publication.

\section{References}

Adaskaveg JE (2008). UC IPM pest management guidelines: Citrus. UC ANR publication 3441. Available at: http://www.ipm.ucdavis.edu/PMG/r107102111.html.

Agostini JP, PM Bushong, A Bhatia, LW Timmer (2003). Influence of environmental factors on severity of citrus scab and melanose. Plant Dis 87:1102-1106

Agustí M, V Almela, M Juan, F Alférez, FR Tadeo, L Zacarías (2001). Histological and physiological characterization of rind breakdown of Navelate sweet orange. Ann Bot 88:415-422

Agustí M, V Almela, S Zaragoza, R Gazzola, E Primo-Millo (1997). Alleviation of peel pitting of 'Fortune' mandarin by the polyterpene pinolene. J Hortic Sci 72:653-658

Ahmed M (2005). Nature and Extent of Fruit Blemishes in Kinnow mandarin. M.Sc. (Horticulture) Thesis. Institute of Horticultural Sciences, University of Agriculture, Faisalabad, Pakistan

Ahmad S, ZA Chatha, M Nasir, A Aziz, NA Virk, AR Khan (2006). Effect of pruning on the yield and quality of Kinnow fruit. J Agric Soc Sci 2:51-53

Albrigo LG (2004). Climate affects flowering, fruit set and quality of citrusA review. In: Proceedings of the International Society of Citriculture $X$ Congress, pp:278-283. Agadir, Morocco

Albrigo LG (1978). Occurrence and identification of preharvest fruit blemishes in Florida citrus orchards. Proc Flor State Hortic Soc 91:78-81

Albrigo LG (1976). Influence of prevailing winds and hedging on citrus fruit wind scar. Proc Florid State Hortic Soc 89:55-59

Albrigo LG (1972). Distribution of stomata and epicuticular wax on oranges as related to stem-end rind break-down and water loss. J Amer Soc Hortic Sci 97:220-223

Alfaro F, FJ Cuenca, M Esquiva (2003). Problemática actual del piojo rojo de California en la Comunidad Valenciana. Comun Valenc Agrar 13:21-28

Alférez F, L Zacarias (2001). Postharvest pitting in navel oranges at nonchilling temperature: Influence of relative humidity. Acta Hortic 553:307-308

Alférez F, B Alquézar, JK Burns, L Zacarías (2010). Variation in water, osmotic and turgor potential in peel of 'Marsh' grapefruit during development of postharvest peel pitting. Postharv Biol Technol $56: 44-49$

Alférez F, Y Lluch, JK Burns (2008). Phospholipase A (2) and postharvest peel pitting in citrus fruit. Postharv Biol Technol 49:69-76
Alférez F, M Agustí, L Zacarias (2003). Postharvest rind staining in Navel oranges is aggravated by changes in storage relative humidity: Effect on respiration, ethylene production and water potential. Postharv Biol Technol 28:143-152

Alquézar B, C Mesejo, F Alférez, M Agustí, L Zacarías (2010). Morphological and ultrastructural changes in the peel of 'Navelate' oranges in relation to variations in relative humidity during postharvest storage and development of peel pitting. Postharv Biol Technol 56:163-170

Ampatzidis Y (2019). Precision agriculture technologies in Citrus. Citrus Industry News http://citrusindustry.net/2019/06/04/precisionagriculture-technologies-in-citrus/ (Assessed: 08 August 2020)

Anonymous (2017). Using copper sprays to control diseases in citrus. Prime Fact $757,2^{\text {nd }}$ Edition, Agriculture NSW, NSW Department of Primary Industries, Australia

Anonymous (2015). Kinnow not exported to EU for quality checks. Available at: https://www.thenews.com.pk/print/28229-kinnow-notexported-to-eu-for-quality-checks (Accessed: 13 May 2012)

Anonymous (2006). Windbreaks for citrus. Available at: https://www.dpi.nsw.gov.au/ agriculture/hort-iculture /citrus/content/.../windbreaks (Assessed: 28 May 2018)

Anonymous (2004). Good plant protection practice: Citrus. Bonne pratique phytosanitaire. EPPO/OEPP Bull 23:34-43

Anonymous (1999). Standard for limes CXS 213-1999. Codex Alimentarius. Food and Agriculture Organization of the United Nations (FAO)

Argolo PS, N Banyuls, S Santiago, O Molla, JA Jacas, A Urbaneja (2013). Compatibility of Phytoseiulus persimilis and Neoseiulus californicus (Acari: Phytoseiidae) with imidacloprid to manage clementine nursery pests. Crop Prot 43:175-182

Arpaia ML, LG Morse (1991) Citrus thrips Scirtothrips citri (Moulton) (Thysanoptera: Thripidae) scarring and navel orange fruit quality in California. J Appl Entomol 111:28-32

Aurambout, JP, J Finlay, J Luck, GA Beattie (2009). A concept model to estimate the potential distribution of the Asiatic citrus psyllid (Diaphorina citri Kuwayama) in Australia under climate change-A means for assessing biosecurity risk. Ecol Model 220:2512-2524

Barman JC, X Zeng (2014). Effect of guava leaf extract on citrus attractiveness to Asian citrus psyllid, Diaphorina citri Kuwayama. Pak J Zool 46:1117-1124

Bassanezi RB, LH Montesino, ES Stuchi (2009). Effects of huanglongbing on fruit quality of sweet orange cultivars in Brazil. Eur J Plant Pathol 125:565-572

Behlau F, LHM Scandelai, G Jos, EDS Junior, FEA Lanza (2017). Soluble and insoluble copper formulations and metallic copper rate for control of citrus canker on sweet orange trees. Crop Prot 94:185-191

Ben-Yehoshua S, J Peretz, R Moran, B Lavi, JJ Kim (2001). Reducing the incidence of superficial flavedo necrosis (noxan) of 'Shamouti' (Citrus sinensis, Osbeck). Postharv Biol Technol 22:19-27

Ben-Yehoshua S, B Shapiro, ZE Chen, S Lurie (1983). Mode of action of plastic film in extending life of lemon and pepper fruits by alleviating water stress. Plant Physiol 73:87-93

Blanke MM, F Lenz (1989). Fruit photosynthesis. Plant Cell Environ 12:31-46

Blasco MJ, A Tena, P Vanaclocha, A Cambra, A Urbaneja, C Monzo (2010). Efficacy of micro-encapsulated formulation compared with sticky barrier for excluding ants from citrus canopies. J Appl Entomol 135:467-472

Blasco J, N Aleixos, J Gómez, E Moltó (2007). Citrus sorting by identification of the most common defects using multispectra computer vision. J Food Eng 83:384-393

Bove JM (2006). Huanglongbing: A destructive, newly emerging, centuryold disease of citrus. J Plant Pathol 88:7-37

Brodrick HT (1970). Accentuation of blemish marks by copper fungicide sprays. African Citrus Manual

Broom JC, DR Donaldson (2010). Bordeaux mixture. Publication 7481. University of California Statewide Integrated Pest Management Program Agriculture and Natural Resources. University of California, Davis, CA 95616. Available online: http://ipm.ucanr.edu/PMG/PESTNOTES/pn7481.html 
Broughton S, FD Lima (2002). Monitoring and control of thrips in citrus. Farmnote. Department of Agriculture, Government of Western Australia Brown G (2009). Minimising sunburn damage to fruit. Aust Fruitgrow 3:14-18 Budagovskaya ON (1997). Analysis of fruit surface quality by phase optics methods. Tekh Russ 27:12-16

Cataldo J, V Durañona, R Pienika, P Pais, A Gravina (2013). Wind damage on citrus fruit study: Wind tunnel tests. $J$ Wind Eng Ind Aerodynam 116:1-6

Chagas M, JR Parra (2000). Phyllocnistis citrella Stainton (Lepidoptera: Gracillariidae): rearing technique and biology at different temperatures. Anais Soc Entomol Bras 29:227-235

Chaparro JX (2004). Breeding a red-fleshed mandarine (candidate gene analysis). Citrus Research Board, Annual Report, Horticultural Sciences, University of Florida, Gainesville, Florida, USA

Cheng R (2003). The attack regularity of citrus fruit fly and its control. Niejiahe Agricultural Technology Extension Station, Yidu municipality, Hubei, China. South China. Fruits 32:17-18

Chung KR (2011). Elsinoe fawcettii and Elsinoe australis: The fungal pathogens causing citrus scab. Mol Plant Pathol 12:123-135

Cohen E, H Safran, D Zotra, Z Volcani (1979). Brown pit in 'Shamouti' orange peel. Alon H'anotea, (in Hebrew)

Cronje PJR (2015). Could ethylene metabolism in lemon fruit influence peteca incidence? Acta Hortic 1065:1455-1461

Cronje PJR (2013). Postharvest rind disorders of 'Nadorcott' mandarin are affected by rootstock in addition to postharvest treatments. Acto Hortic 1007:111-117

Cronje PJR (2007). Postharvest rind disorder of citrus fruits. Citrus Research International, Nelspruit, South Africa

Cronje PJR, OP Stander, KI Theron (2014). Fruit splitting in citrus. Hortic Rev 41:177-200

Cronje PJR, M Huysamer, G Barry (2011a). Postharvest rind breakdown (RBD) of 'Nules Clementine' Mandarin: Symptom development and factors affecting incidence. $S$ A Fruit J 10:62-67

Cronje PJR, GH Barry, M Huysamer (2011b). Fruiting position during development of Nules Clementine mandarin affects the concentration of K, Mg and Ca in the flavedo. Sci Hortic 130:829-837

Danedekar AM (2004). Improving peel quality of California citrus fruit. Citrus Research Board, Annual Report, Horticultural Sciences, University of Florida, Gainesville, Florida, USA

Das AK (2003). Citrus canker- A review. J Appl Hortic 5:52-60

Davies FS (1997). An overview of climatic effects on citrus flowering and fruit quality in various parts of the world. Proc Citrus Flowering and Fruit Short Course, pp:1-4. IFAS, Citrus Research and Education Center, University of Florida, Lake Alfred, Florida, USA

Desneux N, A Decourtye, JM Delpuech (2007). The sublethal effects of pesticides on beneficial arthropods. Ann Rev Entomol 52:81-106

Dewdney MM (2019). Greasy spot. Florida citrus production guide. Institute of Food and Agricultural Sciences, University of Florida, Gainsville, Florida, USA

Dobrzanski B, R Rybczynski (2002). Color change of apple as a result of storage, shelf life and bruising. Intl Agrophy 16:261-268

Duarte AMM, JL Guardiola (1995). Factors affecting rind pitting in the mandarin hybrids "Fortune" and "Nova". The influence of exogenous growth regulators. Acta Hortic 379:59-66

El-Tanany MM, AMA Kheder, HR Abdallah (2019). Effect of some treatments on reducing sunburn in Balady mandarin fruit trees (Citrus reticulata, Blanco). Middle East J Agric Res 8:889-897

FAOSTAT (2018). Food and Agriculture Organization of the United Nations. Available online with updates at http://faostat3.fao.org/browse/Q/E (Assessed: 09 August 2018)

FaroMenge JA (2000). Septoria spot. In: Compendium of Citrus Diseases, $2^{\text {nd }}$ edn, pp:32-33. Timmer LW, SM Garnsey, JH Graham (Eds.). The American Phytopathological Society, Saint Paul, Minnesota, USA

Farooq M, N Ilyas, N Ilyas, I Khan, A Saboor, S Khan, MN Khan, A Qayum, M Bakhtiar (2018). Antifungal activity of plant extracts and silver nano particles against Citrus brown spot pathogen (Alternaria citri). Intl J Environ Agric Res 4:118-125

Fatima A, MU Ghazanfar, W Raza, S Ahmad (2019). Screening of citrus cultivars against citrus canker and its allelopathic management. $J$ Agric Hortic Res 2:1-6
Fischer IH, MD Ferreira, MB Sposito, L Amorim (2009). Citrus postharvest diseases and injuries related to impact on packing lines. Sci Agric 66:210-217

Fleming CA, JT Trevors (1989) Copper toxicity and chemistry in the environment: A review. Water Air Soil Pollut 44:143-158

Freeman B (1976). Rind blemishes of citrus. I. Initiation and development. Sci Hortic 4:317-327

Freeman B (1973). Controlling rind blemish in citrus fruit, p:38. Fruit World Market Grower

Futch HS (2011). Identification of mites, insects, diseases, nutritional symptoms and disorders on citrus. University of Florida, Institute of Food and Agricultural Sciences, Florida, USA

Garcera CE, E Molto, P Chueca (2011). Effect of spray volume of two organophosphate pesticides on coverage and on mortality of California red scale Aonidiella aurantia (Maskell). Crop Prot 30:693-697

Garnier M, S Jagoueix-Eveillard, HF Cornje, LPR Roux, JM Bove (2000). Genomic characterization of a Liberibacter present in an ornamental rutaceous tree, Calodendrum capense, in the Western Cape province of South Africa. Proposal of Candidatus Liberibacter africanus subspp. capensis? Intl J Syst Evol Microbiol 50:2119-2125

Glenn DM (2012). The mechanisms of plant stress mitigation by kaolinbased particle films and applications in horticulture and agricultural crops. Hortic Sci 47:710-711

Goell A, H Safran, Y Erner (1988). 'Juice spot'-A rind disorder in 'Star Ruby' red grapefruit in Israel. In: Citriculture: Proceedings of the Sixth International Citrus Congress: Middle East, Tel Aviv, Israel, pp:1-5.March 6-11, 1998. Goren R, K Mendel (Eds.). Rehovot, Israel

Gonzalez MQ (2000). Phytophagous mite populations on Tahiti lime, Citrus latifolia under induced drought conditions. Exp Appl Acarol 24:897-904

Gopal K, B Govindarajulu, KTV Ramana, CSK Kumar, V Gopi, TG Sankar, L Mukunda, TN Lakshmi, G Sarada (2014a). Citrus scab (Elsinoe fawcettii): A Review. J Agric Allied Sci 3:49-58

Gopal K, LM Lakshmi, G Sarada, T Nagalakshmi, TG Sankar, V Gopi, KTV Ramana (2014b). Citrus melanose (Diaporthe citri Wolf): A review. Intl J Curr Microbiol Appl Sci 3:113-124

Grafton-Cardwell EE, S Doria (2020). Citrus thrips insecticide trial, 2019. Arthr Manage Tests 45:1-2

Gravina A, J Cataldo, G Gambetta, E Pardo, C Fornero, S Galiger, R Pienika (2011). Relation of peel damage in citrus fruit to wind climate in orchard and its control. Sci Hortic 129:46-51

Green GC (1968). Windbreaks for citrus orchards. Farming in South Africa. Citrus Subtrop. Fruit Res Inst Nelspruit 44:9-15

Grierson W (1986). Physiological disorders. In: Fresh Citrus Fruit, Avi Publishing Company, pp:361-378. Wardowski W, S Nagy, W Grierson (Eds.). Westport, Connecticut, USA

Gurr GM, M You (2016). Conservation biological control of pests in the molecular era: New opportunities to address old constraints. Front Plant Sci 6; Article 1255

Halbert SE, KL Manjunath (2004). Asian citrus psyllids (Sternorrhyncha: Psyllidae) and greening disease of citrus: A literature review and assessment of risk in Florida. Fla Entomol 87:330-353

Hardy S, N Donovan (2007). Managing lemon scab in citrus. Primefacts $750: 1-2$

Hasan MU (2018). Optimizing Kinnow production technology for reducing rind blemishes and improving quality. M.Sc. (Horticulture) Thesis. Institute of Horticultural Sciences, University of Agriculture, Faisalabad, Pakistan

Hasan MU, AU Malik, R Anwar, BA Saleem, SA Khan, MS Shah (2018) Effect of Nativo fungicide on disease incidence causing rind blemishes in young Kinnow mandarin (Citrus nobilis Lour $\times$ Citrus deliciosa Tenora). In: $1^{\text {st }}$ Annual Postgraduate Students Research Symposium. Institute of Horticultural Sciences, University of Agriculture, Faisalabad, Pakistan

Headrick DH (2004). Ecological studies, management, and natural enemy releases for citrus peel miner, Marmara gulosa in the central valley. In: Annual Report. Davis, G (Ed.). Citrus Research Board, Horticultural Sciences, University of Florida, Gainesville, Florida, USA 
Hopkins EF, AA Mccornack (1961). Effect of delayed handling and other factors on rind break-down and decay in oranges. Proc Florida State Hortic Soc 73:263-269

Huan FN, LS Li, JL Chen (1992). A preliminary study on the damage and action threshold of citrus rust mite to citrus. Acta Phytol Sin 19:223-230

Huang MD, BL Tan, RQ Mao, YG Chen, GAC Beattie, DJ Rae, DM Watson, YJ Cen, JC Quan, ML Tang, CX Chen, ST Xie, ZH Zhang, QY Yang (2001). Demonstration of horticultural mineral oil based citrus IPM program in China. In: Spray Oils Beyond 2000, pp:372-378. Gac B, DM Watson, ML Stevens, DJ Rae, RN SpoonerHart (Eds.). University of Western Sydney, Sydney, Australia

Jahangir MB (2018). Horticultural mineral oil application to improve cosmetic fruit quality of Kinnow mandarin. M.Sc. (Horticulture) Thesis. Institute of Horticultural Sciences, University of Agriculture, Faisalabad, Pakistan

James DG (1991). An evaluation of chemical and physical treatments to prevent Fuller's rose weevil oviposition on citrus fruit. Plant Prot Quart 6:79-81

Jamieson L, P Stevens (2006). The effect of mulching on adult emergence of Kellys citrus thrips (Pezothrips kellyanus). N Z Plant Prot 59:42-46

Jamieson L, J Charles, P Stevens, C McKenna, R Bawden, (2005). Natural enemies of citrus red mite (Panonychus citri) in citrus orchards. $N Z$ Plant Prot 58:299-305

Javed N, R Ahmed, SA Anwar, M Javed, A Zia (2007). Citrus diseases and their management. In: Proceedings International Symposium on Prospects of Horticultural Industry in Pakistan. 28-30 march, 2007, Institute of Horticultural Sciences, University of Agriculture, Faisalabad, Pakistan

Junior JWC, JB Júnior, L Amorim, RSC Christiano, JRP Parra, AB Filho, (2006). Injuries caused by citrus leafminer (Phyllocnistis citrella) exacerbate citrus canker (Xanthomonas axonopodis pv. citri) infection. Fitopatol Bras 31:277-283

Karmakar R, G Kulshrestha (2009). Persistence, metabolism and safety evaluation of thiamethoxam in tomato crop. Pest Manage Sci 65:931-937

Kennelly MM, FM Cazorla, A Vicente (2007). Pseudomonas syringae diseases of fruit trees: Progress toward understanding and control. Plant Dis 91:4-17

Kerns D, G Wright, J Loghry (2004). Cottony-cushion scale (Icerya purchasi). Cooperative extension, The University of Arizona, College of Agriculture Tucson, Arizona 85721. Available at: http://cals.arizona.edu/crops/citrus/insects/citrus insect.html

Ketchie DO, AL Ballard (1968). Environments which cause heat injury to 'Valencia' oranges. J Amer Soc Hortic Sci 93:166-172

Khalid MS (2013). Kinnow mandarin (Citrus reticulata Blanco) fruit quality in major production districts and strategies for cosmetic improvement. Ph.D. Thesis. Institute of Horticultural Sciences, University of Agriculture, Faisalabad, Pakistan

Khalid S, AU Malik, BA Saleem, AS Khan, MS Khalid, M Amin (2012a). Tree age and canopy position affect rind quality, fruit quality and rind nutrient content of 'Kinnow' mandarin (Citrus nobilis Lour $\times$ Citrus deliciosa Tenora). Sci Hortic 135:137-144

Khalid MS, AU Malik, AS Khan, BA Saeem, N Javed (2012b). Horticultural mineral oil application and tree canopy management improve cosmetic fruit quality of Kinnow mandarin. Afr J Agric Res $7: 3464-3472$

Khumalo NP (2006). Factors affecting post-storage quality of 'Nules Clementine' mandarin fruit with special reference to rind breakdown. M.Sc. thesis. University of Stellenbosch, Stellenbosch, South Africa

Knight TG, A Klieber, M Sedgley (2002). Structural basic of rind disorder oleocellosis in Washington Navel orange (Citrus sinensis L. Osbeck). Ann Bot 90:7665-7773

Krajewski A, TM Pittaway (2002). Common defects associated with degreeing of citrus. Citrus Research International, Nelspruit, South Africa

Ladaniya MS (2008). Citrus fruit biology technology and evaluation. Academic press, U.S.A.
Lado J, PJR Cronje, MJ Rodrigo, L Zacarías (2019). Citrus. In: Postharvest Physiological Disorders in Fruits and Vegetables. Freitas STD, S Pareek, B Raton (Eds.). CRC Press, Taylor \& Francis Group, New York, USA

Lafuente MT, L Zacarias (2006). Postharvest physiological disorders in citrus fruit. Stewart Postharv Rev 1:1-9

Lafuente MT, L Zacarias, JM Sala, MT Sánchez-Ballesta, MJ Gosalbes, JF Marcos, L González-Candelas, Y Lluch, A Granell (2005) Understanding the basis of chilling injury in citrus fruit. Acta Hortic 682:831-842

Lamichhane JR, E Osdaghi, F Behlau, JB Jones, J Aubertot (2018). Thirteen decades of antimicrobial copper compounds applied in agriculture. A review. Agron Sustain Dev 38:28-45

Lim UT, MA Hoy (2006). Overwintering of the citrus leaf miner, Phyllocnistis citrella (Lepidoptera: Gracillariidae), without diapause in Florida. Flor Entomol 89:361-366

Lorente D, M Zude, C Regen, L Palou, J Gomez-Sanchis, J Blasco (2013). Early decay detection in citrus fruit using laser-light backscattering imaging. Postharv Biol Technol 86:424-430

Lee TC, PJ Zhong, PT Chang (2015). The effects of preharvest shading and postharvest storage temperatures on the quality of 'Ponkan' (Citrus reticulate Blanco) mandarin fruits. Sci Hortic 188:57-65

Leksomboon C, N Thaveechai, W Kositratana (2001). Potential of plant extracts for controlling citrus canker of lime. Kasetsart J Nat Sci 35:392-396

Leong SCT, F Abang, A Beattie, RJH Kueh, SK Wong (2012). Impacts of horticultural mineral oils and two insecticide practices on population fluctuation of Diaphorina citri and spread of Huanglongbing in a citrus orchard in Sarawak. Sci World J 2012; Article 651416

Lu YH, KM Wu, YY Jiang, YY Guo, N Desneux (2012). Widespread adoption of Bt. cotton and insecticide decrease promotes biocontrol services. Nature 487:362-365

Maia MI, MC Medeira, MJ Pinto, AM Duarte (2004). Pre-harvest rind stain of 'Encore' mandarin: Initial histological signs of epicarp disturbance and extent of the disorder. Sci Hortic 99:143-152

Malik AU, IA Khan (2014). Kinnow quality: Issues and strategies for improvement, survey report and citrus blemishes resource guide, pp:1-30. University of Agriculture, Faisalabad, Pakistan

Malik AU, MU Hasan, M Waqas, BA Saleem, R Anwar, SA Khan, MH Bashir (2019). Developing technology packaging rind blemishes and quality improvement in young Kinnow orchard: A case study. In: First International Conference on Horticultural Crops and Products Protection, September 19-20, 2019. University of Sargodha, Pakistan

Malik AU, MU Hasan, RNU Rehman, R Anwar, BA Saleem, A Hussain (2018). Comparison of geometric location of trapes on trapped adults of fruit fly and population dynamics in orchard of young Kinnow mandarin. In: International Horticulture Conference. PMAS Arid Agriculture University, Rawalpindi, Pakistan

Martinez D (1995). Causas de descarte zafra. Citrus 27:18-19

Maul P, G McCollum, CL Guy, R Porat (2011). Temperature conditioning alters transcript abundance of genes related to chilling stress in 'Marsh' grapefruit flavedo. Postharv Biol Technol 60:177-185

Mazhar MS (2007). Factors affecting fruit blemishes in Kinnow mandarin. M.Sc. (Horticulture) Thesis. Institute of Horticultural Sciences, University of Agriculture, Faisalabad, Pakistan

Mazhar MS, AU Malik, A Jabbar, OH Malik, MN Khan (2016). Fruit blemishes caused by abiotic and biotic factors in Kinnow mandarin. Acta Hortic 1120:483-490

Mazhar MS, AU Malik, OH Malik (2007). Fruit blemishes caused by abiotic factors in Kinnow mandarin (Citrus reticulate Blanco). In Proceedings International Symposium on Prospects of Horticultural Industry in Pakistan. Institute of Horticultural Sciences, University of Agriculture, Faisalabad, Pakistan

Medeira MC, MI Maia, E Neto, MN Rodrigues (2000). Manchas da tangerina 'Encore'. contributo para o conhecimento das causa das lesões. In: Actas do Congresso Nacional de Citricultura, pp:423432. 16-18 November,

Millar J (2004). Development of Pheromone Traps for Monitoring Citrus Leaf miner. Citrus Research Board, Annual Report, Horticultural Sciences, University of Florida, Gainesville, Florida, USA 
Montero CRS, LL Schwarz, LC Dos-santos, RP Dos-santos, RJ Bender (2012). Oleocellosis incidence in citrus fruit in response to mechanical injuries. Sci Hortic 134:227-231

Naeem A, S Freed, FL Jin, M Akmal, M Mehmood (2016). Monitoring of insecticide resistance in Diaphorina citri Kuwayama (Hemiptera: Psyllidae) from citrus groves of Punjab, Pakistan. Crop Prot 86:62-68

Nasir M, AS Khan, SMA Basra, AU Malik (2016). Foliar application of moringa leaf extract, potassium and zinc influence yield and fruit quality of Kinnow mandarin. Sci Hortic 210:227-235

Nawaz R, NA Abbasi, IA Hafiz, A Khalid, T Ahmad, M Aftab (2019). Impact of climate change on Kinnow fruit industry of Pakistan. Agrotechnology 8; Article 186

Nile AS, YD Kwon, SH Nile (2019). Horticultural oils: Possible alternatives to chemical pesticides and insecticides. Environ Sci Pollut Res 261:21127-21139

Niu JH, H Hull-Senders, YX Zhang, JZ Lin, W Dou, JJ Wang (2014). Biological control of arthropod pests in citrus orchards in China. Biol Contr 68:15-22

Nguyen VC, VL Nguyen, VL Pham (2001). Development of petroleum derived spray oil and natural enemy based integrated pest and disease management program for citrus in North Vietnam. In: Spray Oils Beyond 2000, pp:362-368. Gac B, DM Watson, ML Stevens, DJ Rae, RN Spooner-Hart (Eds.). University of Western Sydney, Australia

Orphanids G (1998). Thrips on citrus. Annual review for 1997, p:30. Agricultural Research Institute. Nicosia, Cyprus

Owen-Turner J, S Hardy (2006). Windbreaks for citrus - Citrus fact sheet, pp:1-15. CITT group, Australia

Partel V, L Nunes, P Stansly, Y Ampatzidis (2019). Automated visionbased system for monitoring Asian citrus psyllid in orchards utilizing artificial intelligence. Comput Electr Agric 162:328-336

Paull RE (1990). Chilling injury of crops of tropical and subtropical origin. In: Chilling Injury of Horticultural Crops, pp:17-36. CRC Press, Boca, Raton, Florida, USA

Peever TL, G Su, L Carpenter-Boggs, LW Timmer (2004). Molecular systematic of citrus-associated Alternaria spp. Mycologia 96:119-134

Peres NA, LW Timmer (2006). Evaluation of the alter-rater model for spray timing for control of Alternaria brown spot on Murcott tangor in Brazil. Crop Prot 25:454-460

Peres NR, NL Souza, EL Furtado, LW Timmer (2004). Evaluation of systems for timing of fungicide sprays for control of post bloom fruit drop of citrus in Brazil. Plant Dis 88:731-735

Petracek PD, H Dou, I Malik (1998). A postharvest pitting of temple oranges stimulated by high temperature storage and wax application. Proc Annu Meet Florida State Hortic Soc, 110:211-214

Porat R, B Weiss, L Cohen, A Daus, N Aharoni (2004). Reduction of postharvest rind disorders in citrus fruit by modified atmosphere packaging. Postharv Biol Technol 33:35-43

Powell AC, MS Burton, R Pelosi, RA Ritenour, RA Bullock (2007). Seasonal abundance and insecticidal control of citrus leaf miner in a citrus orchard. Hortic Sci 42:1636-1638

Prakash A, J Rao (1997). Botanical pesticides in agriculture. CRC Lewis Publishers, Boca Raton, Florida, USA

Raetano CG, MR Kobayashi, WR Kuwahara, RR Vinchi (2003). Application methods and dosages of thiamethoxam in thrips control on tomato plants. Hortic Bras 21:429-432

Rakhshani E (2002). Principles of Agricultural Toxicology, p: 374. Farhange Jame Publication, Tehran, Iran

Rattanpal HS, G Singh, S Singh, A Arora (2017). Citrus Cultivation in Punjab. Department of Fruit Science Punjab Agricultural University Ludhiana, $1^{\text {st }}$ edn. Ludhiana, India

Rebollar-Alviter A, M Nita (2011). Optimizing fungicide applications for plant disease management: Case studies on strawberry and grape. In: Fungicides, pp:1-18. Available at: 10.5772/26740

Rehman A, R Muqbool, MW Alam, S Mehboob (2016). Exploration of ethanolic extracts of parthenium and lemon grass for management of citrus scab (Elsinoe fawcettii). Pak J Phytopathol 28:101-106

Ritenour MA, H Dou (2003). Stem-end rind breakdown of citrus fruit. Institute of Food and Agricultural Sciences (Extention), University of Florida, Gainsville, Florida, USA
Ritenour MA, RR Pelosi, MS Burton, EW Stover, H Dou, TG McCollum (2004). Assessing the efficacy of preharvest fungicide applications to control postharvest diseases of Florida citrus. Hortic Technol 14:58-62

Roberts PD, LW Timmer (2001). Greasy spots. In: Florida Citrus Pest Management Guide, p:144. Florida Cooperative Extension Services, IFAS, Gainesville, Florida, USA

Roger S (1988). Defectos y alteraciones de los frutos cítricos en su comercialización. Edita: Comité de Gestión para la exportación de frutos cítricos. Ed. Lit. Nicolau, Valencia

Sabar M (2011). Acute and population level toxicity of imidacloprid and fenpyroximate on an important egg parasitoid, Trichogramma cacoeciae (Hymenoptera: Trichogrammatidae). Ecotoxicology 20:1476-1484

Safran H (1975). Physiological disorders, environmental and chemical injuries of citrus. In: Blemishes and Deficiencies of Citrus in Israel, pp:110-115. Porat A (Ed.). Sifriat Hapoalim, Tel Aviv, Israel (in Hebrew)

Sala JM (1998). Involvement of oxidative stress in chilling injury in coldstored mandarin fruits. Postharv Biol Technol 13:255-261

Salem SA, AME Salam, AS Reda, MA Abdel-Raheem, FM EL-Hawary (2017). Evaluate and assess the use of some insecticides of plant origin Scritothrips citri Moulton (Thysanoptera, Thripidae) in reducting distortion orange fruits for export. Biosci Res 14:354-361

Sallato B, C Bonomelli, J Martiz (2017). Differences in quality parameters and nutrient composition in Fukumoto oranges with and without creasing symptoms. J Plant Nutr 40:954-963

Santos HP, AAR Oliveira (2004). Oleocelose (Mancha de óleo dos citros). Embrapa

Sarwar M (2015). Attraction of female and male fruit flies (Diptera: Tephritidae) to bait spray applications for reduction of pest populations. Intl J Anim Biol 1:225-230

Schrader L, J Sun, J Zhang, D Felicetti, J Tian (2008). Heat and lightinduced apple skin disorders: Causes and prevention. Acta Hortic 772:51-58

Schrader L, J Zhang, J Sun (2003). Environmental stresses that cause sunburn of apple. Acta Hortic 618:497-503

Schrader LE, J Zhang, WK Duplaga (2001). Two types of sunburn in apple caused by high fruit surface (peel) temperature. Plant Health Progr 2:3. (Accessed: October 30, 2008)

Shareef MF, ABM Raza, MZ Majeed, KS Ahmed, W Raza, HF Hussain (2016). Plant extract as selective pesticide for integrated pest management. Biotechnol Res $J$ 2:6-10

Shi WB, MG Feng (2006). Field efficacy of application of Beauveria bassiana formulation and low rate pyridaben for sustainable control of citrus red mite Panonychus citri (Acari: Tetranychidae) in orchards. Biol Cont 39:210-217

Siddiquee TA, MR Islam, FM Aminuzzaman, AN Faruq, MM Islam (2011). Efficacy of foliar spray with seven fungicides and a botanical to control scab (Elsinoe fawcettii) and dieback (Colletotrichum gloeosporioides) diseases of lemon. Agriculturists 9:99-105

Smart RE, TR Sinclair (1976). Solar heating of grape berries and other spherical fruits. Agric Meteorol 17:241-259

Smit A (2007). Apple tree and fruit responses to shade netting. Master Thesis. Master of Science in Agriculture, Department of Horticultural Science, University of Stellenbosch, South Africa

Smith R (1999). Shedding Light on Pruning Orange Trees. California Citrus Manual

Srivastava AK (2013). Nutrient deficiency symptomology in citrus: An effective diagnostic tool or just an aid for post-mortem analysis. Agric Adv 2:177-194

Storey R, MT Treeby (2002). Cryo-SEM study of early symptoms of peteca spot in 'Lisbon' lemon. J Hortic Sci Biotechnol 77:551-556

Talebi-Jahromi K (2007). Pesticide Toxicology, p:492. University of Tehran Publication, Tehran, Iran

Taverner P, B Tugwell, B Wild (2001). A guide to the common postharvest diseases \& disorders of navel oranges and mandarins grown in inland Australia. South Australian Research and Development Institute (SARDI), Adelaide, Australia 
Teixeira DC, AJ Ayres, EW Kitajima, FAO Tanaka, JL Danet, SJ Eveillard (2005). First report of a Huanglongbing-like disease of citrus in São Paulo State, Brazil, and association of a new liberibacter species, "Candidatus liberibacter americanus", with the disease. Plant Dis 89-107

Timmer LW, PD Roberts, KR Chung (2012). Florida citrus pest management guide: Citrus scab, p:146. University of Florida IFAS Extension Publication, Gainesville, Florida, USA

Timmer LW, TL Peever, ZVI Solel, K Akimitsu (2003). Alternaria diseases of citrus-novel pathosystems. Phytopathol Mediter 42:99-112Tiwari S, RS Mann, ME Rogers, LL Stelinski (2011). Insecticide resistance in field populations of Asian citrus psyllid in Florida. Pest Manage Sci 67:1258-1268

Torres-Leal GJ, CM Lamelas, J Forciniti (2004). Meteorological conditions during preharvest and postharvest management affecting peteca incidence in lemon from Tucuman, Argentina. Proc Intl Soc Citricult $3: 1110-1111$

Tsai MS, TC Lee, PT Chang (2013). Comparison of paper bags, calcium carbonate, and shade nets for sunscald protection in 'Murcott' tangor fruit. Hortic Technol 23:659-667

Umeh VC, AA Olaniyan, J Ker, J Andir (2004). Development of citrus fruit fly control strategies for small-holders in Nigeria. Fruits 59:265-274

Vanaclocha P, A Urbaneja, MJ Verdu (2009). Mortalidad natural del piojo rojo de California, Aonidiella aurantii, en cítricos de la Comunidad Valenciana y sus parasitoides asociados. Bol San Veg Plagas 35:59-71

Van-Rensburg PJJ, PJR Cronje, J Joubert, G Gambetta, M Bruwer (2004). Factors influencing rind breakdown in citrus fruit. Proc Intl Soc Citricult 1051-1061

Vasquez C, D Balza, MA Jiménez, Y Colmenárez, Y Rios (2016). Use of plant extracts as an alternative control method against phytophagous mites in South America. Curr Topics Phytochem 13:36-41

Vassiliou VA (2007). Chemical control of Pezothrips kellyanus (Thysanopetra: Thripidae) in citrus plantation in Cyprus. Crop Prot 26:1579-1584

Verreynne S, S Merwe (2011). Sunburn reduction on 'Miho Wase' Satsuma mandarin. S A Fruit J 10:52-55

Vicent A, J Armengol, J García-Jiménez (2009). Protectant activity of reduced concentration copper sprays against Alternaria brown spot on 'Fortune' mandarin fruit in Spain. Crop Prot 28:1-6

Vitor R, F Lidon, C Carvalho, G Barreiro, MI Maia, MC Medeira, A Guerreiro (2000). Peel-pitting of Encore mandarin fruits: Etiology, control and implication in fruit quality. Fruits 56:395-404
Walker GP, N Zareh, ML Arpaia (1999). Effect of pressure and dwell time on efficiency of a high-pressure washer for postharvest removal of California red scale (Homoptra: Diaspidae) from citrus fruit. $J$ Econ Entomol 92:906-914

Waqas M (2019). Integrated techniques for improving fruit quality of Kinnow mandarin. M.Sc. (Horticulture) Thesis. Institute of Horticultural Sciences, University of Agriculture, Faisalabad, Pakistan

Whiteside JO, SM Garnsey, LW Timmer (1988). Compendium of citrus diseases. APS Press, St Paul, Minnesota. USA

Wild BL (1998). New method for quantitatively assessing susceptibility of citrus fruit to oleocellosis development and some factors that affect its expression. Aust J Exp Agric 38:279-285

Wild BL (1991). Postharvest factors governing the development of peteca spot on 'Meyer' lemons. Hortic Sci 26:287-289

Wünsche JN, J Bowen, F Woolf, A Woolf, T Mcghie (2004). Sun-burn on apples causes and control mechanisms. Acta Hortic 636:631-636

Yang Y, JC Allen, JL Knappand, JA Stansly (1994). Citrus rust mite (Acari: Eriophyidae) damage effects on Hamlin orange fruit growth and drop. Environ Entomol 23:244-247

Zacarias L, PJR Cronje, L Palou (2020). Postharvest technology of citrus fruits. In: The Genus Citrus, pp:421-466. Talon M, M Caruso, FGJ Gmitter (Eds.). Elsevier, USA

Zacarias L, F Alferez, N Gariglio, V Almela, M Agusl (2001). Rind breakdown in navelate oranges: Influence of rootstock. In: Proceedings of the International Society on Citricult Orlando, Vol. 1, p:512. Florida, Gainesville, Florida, USA

ZakyMA(2018). Impact of spraying some chemical substances on controlling sunburn of Balady mandarin fruits. Egypt J Hortic 45:229-236

Zaragoza S, V Almela, FR Tadeo, E Primo-Millo, M Agusti (1996). Effectiveness of calcium nitrate and $\mathrm{GA}_{3}$ on the control of peelpitting of 'Fortune'mandarin. J Hortic Sci 71:321-326

Zekri M, A Thomas, Obreza, R Koo (2003). Irrigation, nutrition and citrus fruit quality. University of Florida, IFAS, Gainesville, Florida, USA

Zhang F, Y Li, C Yu, C Pan (2012). Determination of six neonicotinoid insecticides residues in spinach, cucumber, apple and pomelo by quecers method and LC-MS/MS. Bull Environ Contam Toxicol $88: 885-890$

Zhang J, LW Timmer (2007). Preharvest application of fungicides for postharvest disease control on early season tangerine hybrids in Florida. Crop Prot 26:886-893

Zhang Y, WS Lee, M Li, L Zheng, MA Ritenour (2018). Non-destructive recognition and classification of citrus fruit blemishes based on ant colony optimized spectral information. Postharv Biol Technol $145: 119-128$ 